Federal Reserve Bank of Minneapolis

Research Department Staff Report 145/JV

\title{
International Evidence on the Historical Properties of Business Cycles*
}

David K. Backus

Stern School of Business

Patrick J. Kehoe

Federal Reserve Bank of Minneapolis

\begin{abstract}
We contrast properties of real quantities with those of price levels and stocks of money for ten countries over the last century. Although the magnitude of output fluctuations has varied across countries and periods, relations among real quantities have been remarkably uniform. Properties of price levels, however, exhibit striking differences between periods. Inflation rates are more persistent after World War II than before, and price level fluctuations are typically procyclical before World War II, countercyclical afterward. Fluctuations in money are less highly correlated with output in the postwar period, but are no more persistent than in early periods.
\end{abstract}

*The views expressed herein are those of the authors and not necessarily those of the Federal Reserve Bank of Minneapolis or the Federal Reserve System. 


\title{
INTERNATIONAL EVIDENCE ON \\ THE HISTORICAL PROPERTIES OF BUSINESS CYCLES \\ David K. Backus and Patrick J. Kehoe*
}

\begin{abstract}
We contrast properties of real quantities with those of price levels and stocks of money for ten countries over the last century. Although the magnitude of output fluctuations has varied across countries and periods, relations among real quantities have been remarkably uniform. Properties of price levels, however, exhibit striking differences between periods. Inflation rates are more persistent after World War II than before, and price level fluctuations are typically procyclical before World War II, countercyclical afterward. Fluctuations in money are less highly correlated with output in the postwar period, but are no more persistent than in earlier periods.
\end{abstract}

JEL Classification Codes: E32, E31.

We study fluctuations in output, prices, and money in ten countries for which at least a century of annual data is available. We also examine the cyclical behavior of components of national output: private consumption expenditures, fixed investment, government purchases of goods and services, and net exports. Our objective is to document some of the salient features of business cycles. We know that in many respects these countries and time periods have been markedly different. The ten countries differ in their institutions, their monetary and fiscal policies, their industrial compositions and structures, and their average aggregate growth rates. The question is whether they share, despite these differences, similar features of business cycles.

We find a great deal of regularity in the cyclical behavior of real quantities. Although the magnitude of output fluctuations varies across countries and over time, relations among variables are remarkably stable. Investment is consistently two to four 
times as variable as output; consumption is about as variable as output; and both investment and consumption are strongly procyclical. The trade balance is generally countercyclical, exhibiting larger deficits during booms than recessions. The exception to this regularity in quantities is government purchases, which exhibit no systematic cyclical tendency. Patterns of price level fluctuations, however, have changed markedly. Before World War II prices were predominantly procyclical; since then they have been consistently countercyclical. They have also been, in most countries, substantially more persistent since World War II than in earlier periods. We also find for the post-World War II period that fluctuations in the stock of money have been less highly correlated with output. There is no general tendency across countries, however, toward greater persistence of money growth rates.

Our study is an outgrowth of business cycle research by Finn Kydland and Edward Prescott (1990), Robert Lucas (1977), and others that, in turn, retains some of the flavor of the tradition of Arthur Burns and Wesley Mitchell (1946) at the National Bureau of Economic Research (NBER). The goal of this work is, for the most part, to summarize the properties of macroeconomic data without imposing much theoretical structure. The resulting empirical regularities can then serve as a guide to a variety of future theoretical developments. A common theme in this line of research is that the business cycle phenomenon consists not simply of fluctuations in aggregate output, but also of common patterns of correlation between different aggregate time series. We report properties of international fluctuations in a manner that conforms with some recent work on American business cycles and thus extends this work to a much wider range of countries and time periods. Our motivation is international in another respect: our own research (Backus and Kehoe 1987; Backus, Kehoe, and Kydland 1992) concerns the dynamics of international trade and the relationships among business cycles in different countries. A useful by-product is additional evidence on the question, Have output fluctuations since World War II been smaller than those prior to World War I? This question has been the subject of active debate in the United States, including papers 
by Christina Romer (1986, 1989), Nathan Balke and Robert Gordon (1989), and Steven Sheffrin (1988). Like Sheffrin's study, ours puts this debate in an international context. We include several countries not studied by Sheffrin, notably Australia, Canada, and Japan, and introduce new data for Sweden.

Our data set covers ten countries with at least a century of annual data on national output: Australia, Canada, Denmark, Germany, Italy, Japan, Norway, Sweden, the United Kingdom, and the United States. For the most part, countries with national income accounts for such a long period are also those with the highest per capita output today. Several others, including India, report partial time series, but we doubt these series are sufficiently accurate for the study of short-term fluctuations. Estimates of national output in the ten countries vary in quality, but in some cases we think they are superior to the U.S. data.

We begin, in Section I, by describing the data. While data for earlier periods are unquestionably less reliable than modern data, in some countries they appear to be good enough to provide an accurate picture of business cycles prior to World War II. The data for several countries seem to be significantly more accurate than the Kuznets-based estimates for the United States, primarily because raw data sources are better in these countries. In Section II, we compare output volatility before World War I (the prewar period), after World War II (the postwar period), and between the wars (the interwar period). Until recently, the presumption has been that prewar U.S. output fluctuations were two or three times larger than those of the postwar period. Romer (1989), however, suggests that at least part of this difference is the result of systematic measurement error in prewar GNP that overstates its cyclical variability. Our international data set provides additional evidence on this question.

For the ten countries, we find that interwar fluctuations in real output are uniformly larger than those of the postwar period. With the single exception of Japan, the standard deviations of output fluctuations are from two to four times larger in each of the ten. We find, however, no consistent pattern for the prewar/postwar comparison. In 
six of the ten countries, including most of the European countries studied by Sheffrin (1988), prewar fluctuations are no more than 60 percent larger than those of the postwar period. But in the other four (Australia, Canada, Sweden, and the United States) the fluctuations are considerably larger in the prewar period. The U.S. case has been discussed extensively, and it appears that part of the excess volatility of the prewar period can be attributed to measurement error (Romer 1989). Romer's preferred estimate of prewar volatility is only 30 percent higher than for the postwar period, but Balke and Gordon (1989) argue for a number closer to 100 percent. Sheffrin (1988) considers a similar case for Sweden and concludes that the excess volatility in the prewar era is not the result, primarily, of measurement error. We find, as do Michael Bergman and Lars Jonung (1989) with different methods, that about half of the excess volatility Sheffrin finds in the prewar period disappears when revised estimates of prewar output are used. Australia and Canada have the most extreme differences between periods, with output three and two times more volatile, respectively, in the prewar period. The data for both countries are reasonably good, so the greater volatility of measured output probably indicates a change in the variability of real economic activity.

In Section III, we examine the behavior of components of the national product: consumption, gross investment, government spending, and net exports. We find that many of the properties of postwar business cycles in the United States are evident in other countries and periods. Consumption expenditures have been procyclical and have approximately the same standard deviation as output. Investment has also been uniformly procyclical and generally varies, in percentage terms, from two to four times more than output. Government spending has generally been more variable than output, but countercyclical almost as often as procyclical. Net exports has been, for the most part, countercyclical. We also find that correlations between measured output movements in different countries are typically positive, and more pronounced after the second world war than before the first.

In Section IV, we examine movements in price levels and money stocks. Here 
we find, in contrast to the regularity of real quantities, two significant changes in the cyclical behavior of prices. We find, first, that price changes in most countries have been more persistent since the second world war than they were before the first. This finding extends related work by Jeffrey Sachs (1980), Charles Schultze (1986) and John Taylor (1986) on the U.S., and by Gordon (1983) on the U.S., the U.K., and Japan, to a larger set of countries. We also find, in the prewar and interwar periods, that output and price level fluctuations are positively correlated in most of the ten countries. But in the postwar period price fluctuations have been consistently countercyclical. We find a slight decline in the correlation of money and output in the postwar period, but no general tendency for greater persistence of money growth rates. We conclude this section with some speculative remarks on potential explanations for the observed changes in price behavior.

\section{The Data}

We start with a description and evaluation of the data, emphasizing in particular the methods used to construct prewar national income accounts; sources and definitions are described in Appendix A. Although national accounts are based to a large extent on a common framework, sources of raw data differ across countries, especially in the prewar period. Countries with the best source material tend to have the most reliable estimates of national income. The United Kingdom, for example, has had an annual income tax in effect continuously since 1842, while in the United States the federal personal income tax was only made possible in 1913 by the Sixteenth Amendment to the Constitution. As a result, the United Kingdom has much better data on the income side of the national accounts for the prewar period than the United States. In other countries, the establishment of statistical bureaus to measure production and employment, frequently on an industry basis, make production-based accounts feasible. In the United States such sources of annual data are extremely limited. For this reason, and because accounting methods have improved in the decades since Simon Kuznets' (1961) work on 
prewar U.S. GNP, estimates for several of the countries we study are likely to be better than the American data examined by Romer (1989) and Balke and Gordon (1989).

Problems with prewar U.S. data have been well-documented by Kuznets (1961) and Romer (1986, 1989). Kuznets and his coworkers constructed national income accounts for the United States from 1869. The cornerstone of this work, and most later work as well, is William Shaw's (1947) commodity output series: estimates of value added in manufacturing, mining, and farming. Shaw's estimates, and therefore those of national income, were severely constrained in the prewar period by the absence of comprehensive annual data sources. The most informative sources (see Shaw 1947, Part II) were periodic federal censuses, including especially the Census of Manufactures, available every ten years from 1869 to 1899 and every five years from 1899 to 1919 . One source of annual data is reports on industry published by eight states. These states accounted for between 10 and 39 percent of total manufacturing in census years, and the reports typically covered only part of each state's manufacturing output (see Shaw 1947, Table II:4). The state reports were supplemented with occasional government reports and industry publications. Kuznets (1961) interpolated further between the census benchmarks of 1869,1879 , and 1889 , by using a variety of industry output indicators (see the notes to Kuznets 1961, Tables II:1 to II:5), since neither he nor Shaw was able to measure commodity output directly for the 1869-89 period. Finally, both Shaw and Kuznets estimated nominal value added, which was converted to real terms at a disaggregated level using producer price indexes.

Romer (1989), however, bases her criticism of prewar U.S. data not on the fragmentary source material used to produce estimates of commodity output but on the method Kuznets (1961) used to extrapolate from commodity output to GNP. Kuznets' problem was to estimate GNP from information on commodity output alone, since direct measures of other components were not consistently available even for census years. Commodity output accounted for between one-third and one-half of total output in the prewar period; transportation, distribution, and services were missing completely. 
Roughly speaking, Kuznets attributed to total output about the same percentage variability as commodity output. Since commodity output is more volatile than the other components, this procedure probably exaggerates the cyclical variability of GNP. Kuznets points this out himself in a widely cited passage (Kuznets 1961, p. 546) and reports only five-year averages in his book. But the annual series were available in an unpublished manuscript, and they form the basis of most existing series for the prewar period. Our series is taken from Balke and Gordon (1986) and incorporates adjustments to the Kuznets series by Robert Gallman (1966) and themselves that bring it closer to the Commerce Department's current definition of GNP. We return to these measurement issues in Section 3, where we compare the properties of our GNP series with those of series recently estimated by Romer (1989) and Balke and Gordon (1989).

Data for the United Kingdom appear to be considerably better. Charles Feinstein's (1972) compilation and synthesis of British data includes three estimates of real output, based respectively on expenditure, income, and production data. Although the sources overlap, the series were constructed independently (see the discussion in Feinstein 1972, ch. 1, esp. p. 12). The expenditure series, constructed by James Jefferys and Dorothy Walters (1955), uses information on expenditures by detailed commodity group, including agricultural reports, excise tax revenues, indexes of manufacturing output by commodity, and government accounts. Despite the apparently rich source material, expenditures on consumer services are based on linear interpolation between censuses, and distribution costs are simply a constant markup over production costs (Feinstein 1972, p. 17). In this respect the series resembles Kuznets' estimates for the United States. The income-based series, adapted from earlier work by A.R. Prest (1948), estimates aggregate output from factor incomes. Wages were estimated from partial information about employment and wage rates in various industries (the so-called Bowley series); profits and rents were estimated from income tax records. The production, or output, series is based on indexes of real output by industry. All three output series are deflated at a disaggregated level using price indexes from earlier studies. We utilize 
Feinstein's "compromise estimate," an index number that combines the income, expenditure, and output measures using a common deflator. Since the three estimates draw on different sources their measurement errors should be imperfectly correlated, and the compromise estimate should be more accurate than any of the individual series.

N.G. Butlin's (1962) Australian estimates were constructed from production data. They are based on a wealth of raw material arising largely from the central role of government in Australian economic development. Butlin (1962, p. 3) states: "Few, if any, countries can match the range and accuracy of Australian official and private statistics over such a long period. ... [These statistics] provide the basic data with which to estimate industrial subdivisions of total product and, moreover, to do so on an annual basis, without reliance on benchmark procedures." He estimates output for thirteen industrial categories, including the distribution and service sectors. By way of example, good estimates of wool production, one of the larger components of output, are available from reports of production and exports. The sources are generally better after 1900 than before, but even before 1900 there seems to be enough information to construct reasonable measures of aggregate output, expenditure components, and prices.

Early Canadian data, described by M.C. Urquhart (1986), are also derived from production sources. Although the Census of Manufactures, which began in 1870, is only available every ten years in the prewar period, Urquhart and his colleagues marshalled a large body of annual sources to produce annual output series for nineteen industrial classifications. In some cases (mining, railroads) the estimates are based directly on annual measures of industry output; in others, some of the components are interpolated between censuses with indicator series (textile output from cotton imports). On the whole, the resulting nominal aggregate output series are represented as being quite good by the standards of historical work. The weakest component is the price deflator, which is an aggregate estimate of the consumer price index. Before 1900 this index is based on newspaper reports and records of a small number of individual retailers for a single town, Kingston, Ontario (see Urquhart 1986, Appendix 5), so both the price index and the 
implied real output series are of questionable reliability in the earlier period.

The Japanese national accounts compiled by Kazushi Ohkawa, Nobukiyo Takamatsu, and Yuzo Yamamoto (1974) appear to be based on somewhat less comprehensive sources than those of Australia, Canada, and the United Kingdom. Most of the accounts are derived from production data, with extensive interpolation based on annual reports of government ministries; see Ohkawa et al. (1957, Part II). The Ministry of Industry and Commerce, for example, collected statistics on factory output for all factories employing five or more workers, and the Ministry of Agriculture and Commerce collected production quantities for major agricultural categories (e.g., rice, barley, wheat, soy beans). Service and distribution output, particularly in the prewar period, are inferred from indirect estimates of factor payments to labor: the number of people gainfully employed in "tertiary" production is multiplied by a wage rate proportional to the wage in goods-producing sectors; see Ohkawa (1957, pp. 100-115). Real output is estimated by deflating components by their respective price indexes.

Swedish data, reported by Osten Johansson (1967) and Olle Krantz and Carl-Axel Nilsson (1975), stems from the pioneering work of Eric Lindahl, Einar Dahlgren, and Karin Kock (1937) and appears generally to be of high quality. As with most other countries, prewar estimates of national income are constructed from production statistics and built up by industry. The primary sources are annual industrial statistics collected by the Board of Trade as well as agricultural statistics from the Central Bureau of Statistics. These are available in some cases from 1858 or earlier, but they are considerably more reliable and comprehensive after 1895 . For example, mining output prior to 1896 is estimated, as in Canada, from physical quantity indicators. From 1896 on, direct estimates of factor payments and the value of output are available. On the whole these estimates for the prewar period appear to be reasonably good, probably comparable in quality to those of Australia and Canada, but not as good as those of the United Kingdom. Johansson (1967, p. 13) remarks, however, that for the study of business cycles the series are not sufficiently accurate in their year-to-year changes. 
Discussions by Lindahl et al. (1937, esp. pp. 239ff.) and Krantz (1989) suggest that this caveat is overly strong. The weakest part of the Johansson series is the deflation procedure, which uses a single cost-of-living index to deflate aggregate output. Krantz and Nilsson (1975) deflate components separately and make a number of other changes as well.

Data for Norway and Denmark are probably not of the same quality. Norwegian sources (see Norway, Central Bureau of Statistics, Historical Statistics 1978, Section IV), largely production and trade statistics, are reported to be satisfactory for constructing annual data from 1930 onwards. Between 1900 and 1927 only biennial production data are available, and before 1900 not even that, so the early data must be viewed with some skepticism. The Danish data, too, are suspect. Kjeld Bjerke (1955, p. 123) remarks that "the scarcity of basic data involves numerous approximations, particularly for the early period; and the resulting records are useful mainly for delineating the broad trends." It appears, for instance, that the output of both agricultural and nonagricultural industries is computed in the prewar period at least partly from smooth trends between dates for which better data are available, a procedure that is likely to understate short-term variability.

We have even less faith in the German and Italian series, which we obtained from B.R. Mitchell (1976) rather than country sources. For both countries the series were pieced together from several different individual series, and their short-term reliability is questionable. For Germany we have, in addition to the usual shortage of primary data, major changes in the country's physical boundaries over the last century and changes in governmental structure that combined to prevent consistent source material from being collected. In the prewar period the estimated national accounts are based on income tax records, but these too are incomplete. At that time, the tax was collected by 26 individual states (Länder), each with a different tax system. To maintain consistency, the estimates for the prewar period are based on tax statistics for Prussia and Saxony, which accounted for about 70 percent of national income; see Paul Jostock (1955, pp. 81-3). As 
a result of this reliance on income tax sources, estimates of national income and investment are on a net basis, so they are not directly comparable to the gross estimates of other countries. Investment, in particular, exhibits much wilder fluctuations than it does in the other countries and is frequently negative in the interwar period. Early in the interwar period Germany suffered such extreme inflation that it is impossible to make sense of nominal tax records, and no accounts have been estimated.

Viewed as a whole, this international data set contains a great deal of information about business cycles over the last hundred years. Some of this information is presented in Table 1, where we report the means, standard deviations, and autocorrelation coefficients of output growth rates (first differences of logarithms of real output) for each of the ten countries in the prewar, interwar, and postwar periods. The mean rate of growth ranges from a low of 1.22 percent in the interwar United Kingdom to a high of 7.03 percent in postwar Japan. By and large, countries have experienced faster growth since World War II than in either of the two earlier periods, but there is a great deal of variation across countries in all periods. The standard deviation of growth rates has generally been lower in the postwar period than in the other two periods and is highest, for every country except Australia, in the interwar period. The autocorrelation of growth rates has also changed, being positive (sometimes only slightly so) for every country in the postwar period, but generally negative in earlier periods. This reversal might reflect a change in the nature of economic fluctuations, but measurement error is also a possibility, since white noise errors in the output series would have precisely this effect on the autocorrelation of growth rates.

\section{Fluctuations in Real Output}

We turn to a comparison of output volatility over the last hundred years. Throughout the paper, our working definition of business cycle fluctuations concerns properties of time series that have been filtered by the Hodrick-Prescott method, which

removes low-frequency movements from the data; see Appendix B for details. The 
filtering operation can be thought of as removing a smooth trend line, like one might draw freehand, from the data.

We see in Table 2 that the magnitude of output fluctuations - that is, the standard deviation of the Hodrick-Prescott filtered logarithm of real output - has varied substantially over time and across countries. One such change is the reduction of output variability in the United States from 4.28 percent in the prewar period to 2.26 in the postwar period. By this measure, the standard deviation of output fluctuations was 1.9 times larger in the prewar period than it has been since World War II. Similarly, the standard deviation was 4.1 times larger in the interwar period than in the postwar period. The 1.9 interwar-to-postwar ratio of standard deviations is similar to previous volatility comparisons between Kuznets-derived prewar GNP estimates with the Commerce Department's modern series. See Romer's (1989, Table 3, comparison between prewar Gallman-Kuznets GNP and postwar Commerce Department GNP) estimate of 1.93 and Balke and Gordon's (1989, Table 3, line 1, column 9) of 1.85. Their calculations differ in two respects from ours: they compute fluctuations as differences from a piecewise log-linear trend and they extend the "prewar" period to 1928. Neither difference matters much. When we compute the prewar-postwar volatility ratio using the Balke-Gordon sample periods, $1869-1928$ and 1947-86, our volatility ratio changes from 1.90 to 1.82 . Thus the Hodrick-Prescott method of computing fluctuations yields similar measures of relative variability in this case. The absolute measures of variability are also quite close, generally within 10 percent of each other. Our method has two small advantages over theirs: it enforces smoothness on the estimated trend series (piecewise log-linear trends can have sharp kinks) and conforms more closely with recent studies of postwar business cycles; see, for example, Keith Blackburn and Morten Ravn (1991), Peter Brandner and Klaus Neusser (1990), Lawrence Christiano and Martin Eichenbaum (1992), Isabel Correia, Joao Neves, and Sergio Rebelo (1991), Jean-Pierre Danthine and John Donaldson (1991), Kydland and Prescott (1990), and Backus, Kehoe, and Kydland (1992).

Until recently the professional consensus was that output volatility declined 
dramatically after World War II; see, for example, Martin Baily (1978), Burns (1960), Lucas (1977), Taylor (1986), and James Tobin (1980). Romer (1986, 1989), however, argues forcefully that differences in the way real output was measured accounts for a large part of the difference between periods. As we mentioned, the Kuznets real GNP series was estimated from data on commodity output alone, and commodity output in the postwar period has been more than 70 percent more variable than output as a whole (Romer 1989, Table 3). Romer proposes an alternative GNP series that reduces this alleged bias. If we apply our methods to her series, the fluctuations have a standard deviation in the prewar period of 2.64 percent, which is only 1.29 times more volatile than the Commerce Department's postwar series. Balke and Gordon (1989) propose their own series, incorporating information on transportation, construction, and consumer prices not used in earlier estimates. With our methods and their series, prewar volatility is 1.77 times greater than postwar volatility. These disparate results leave us with a fairly large range of uncertainty about the volatility of prewar real output.

Rather than attempt to resolve their debate, we examine data for nine other countries. Although measurement error is a generic problem in the prewar period, the data for several of the countries we study appear to be sufficiently good to provide an accurate account of prewar business cycles. Consider the United Kingdom. As noted earlier, an abundance of raw data led to three largely independent estimates of real output. The one used in our. tables is Feinstein's (1972) compromise estimate, an index that combines the three. Its standard deviation (after filtering) is 31 percent larger in the prewar period than the comparable series in the postwar period, suggesting that prewar cycles were not much different in magnitude than postwar cycles. We can get an idea of the range of uncertainty in this measure by examining the income, expenditure, and output series separately. Since the output series ends in 1913, we use only the 1870-1913 period for this comparison. Fluctuations in the expenditure series have a standard deviation of 2.08 over the period, yielding a prewar/postwar volatility ratio of 1.28 , which is very close to that of the compromise estimate. The output and income series have 
volatility ratios of 1.35 and 1.66 , respectively. The major discrepancy is with the income series. David Greasley (1989) argues that this series, particularly its component Bowley labor-income series, is flawed, and reports new income-based series. With his revisions the volatility ratio falls from 1.66 to 1.43 . Our estimated volatility ratios thus range from 1.28 to 1.66 , but our best measurements indicate that the ratio lies near the lower end of this interval.

Of the remaining eight countries, five have prewar-postwar volatility ratios of 1.6 or less, but three were substantially more volatile in the prewar period: Australia, Canada, and Sweden. Each of these three countries has reasonably good prewar national accounts, so the measured differences between periods probably indicate differences in aggregate market activity. These three countries and the United States are also four of the five most volatile of the interwar period (the fifth being Germany, for which the interwar period was exceptional). Since interwar accounts were generally better than prewar accounts we are again led to conclude that the variability of output in these countries has changed markedly.

In Australia, prewar fluctuations were dominated by the decline and subsequent recovery of the early 1890s. Between 1889 and 1895 real output fell by more than 4 percent in an economy that averaged 3 percent growth per year in the prewar period. Part of this decline can be attributed to the effect of a severe drought on the agricultural sector (from 1894 to 1900 the stock of sheep fell by half), but the timing of the downturn and the behavior of other sectors of the economy suggest that the drought cannot account for most of the fall in aggregate output (see Rodney Maddock and Ian McLean 1987 and E.A. Boehm 1971). Even without this episode, however, measured prewar fluctuations were twice as large as postwar fluctuations: if we omit the years 1888-97 surrounding this recession, the standard deviation of filtered output falls from 6.30 to 4.12 , yielding a prewar/postwar volatility ratio of 2.1 .

Fluctuations in Canada were larger in the prewar than the postwar period, and larger still between the wars. This difference between the prewar and postwar periods - 
a factor of two - is probably too large to attribute to measurement error alone, notwithstanding the difficulties noted earlier with price measurement prior to 1900 .

In Sweden fluctuations are 1.7 times as volatile in the prewar period relative to the postwar period. This number is based on Krantz and Nilsson's (1975) revisions of the Johansson (1967) data used by Sheffrin (1988). As Bergman and Jonung (1989) point out, the revisions make a considerable difference: the standard deviation of prewar fluctuations in Johansson's series is 3.67 rather than 2.43, and the prewar/postwar volatility ratio is 2.5 rather than 1.7 . Similarly, the standard deviation of interwar fluctuations falls from 6.47 with the Johansson data to 3.74 with the Krantz-Nilsson series. There is also an apparent difference within the prewar period. As mentioned, the Swedish national accounts are fairly good by prewar standards, but considerably more reliable after 1895 . We find that when the pre-1895 data are omitted, the standard deviation of prewar output fluctuations falls from 2.43 to 2.03 . This estimate is still 30 percent larger than the standard deviation of postwar fluctuations, but considerably less than the 150 percent difference estimated by Sheffrin (1988) with Johansson's data. This suggests that measurement error accounts for a large part of previously estimated differences between periods.

In short, our estimates indicate that while prewar fluctuations were generally larger than those of the postwar period, the extent of the difference varies across countries, with prewar/postwar ratios of standard deviations ranging from 0.8 to 3.3 . Although some of the differences are likely the result of measurement error in the earlier periods, a careful look at the data suggests that in some cases, at least, they also reflect changes in the variability of real output. The one unavoidable conclusion about changes in variability over time is that the interwar era experienced much larger fluctuations than the other two periods, although the extent of this extra volatility varies from country to country. 


\section{Fluctuations in Expenditure Components}

The term business cycle is commonly used to describe related fluctuations in a wide range of economic activities. This definition applies to the NBER's work on reference cycles, described by Burns and Mitchell (1946) and Geoffrey Moore and Victor Zarnowitz (1986), as well as to more recent work by Kydland and Prescott (1990) and Lucas (1977). Accordingly, we turn to patterns of correlation between different measures of economic activity. In the prewar and interwar periods such efforts are severely constrained by lack of data. Before World War I, estimates of employment, for example, are generally available only once each decade. The availability of unemployment rates mirrors unemployment insurance programs, and in the prewar period these generally covered, if anything, only a small part of the labor force. Financial data, like interest rates and stock market indexes, are available for only a few countries. Canada, for example, had no Treasury-bill market until the 1930s. We are left with various. components of national income: personal consumption expenditures (C), gross investment in fixed capital (I), government spending (G), and net exports (NX).

In most cases these expenditure components are available from the same sources as national income and thus have similar reliability. Gross investment, for instance, is available for most countries that have national income estimates. The exception in our sample is Germany, for which only a net investment series exists. Since a large fraction of fixed investment in the prewar years was performed by governments, and since the boundary between private and government activity varies, we include, where possible, government capital formation in our investment series: Doing so enables us to include, for instance, government-sponsored railroad construction in Australia and Japan. Consumption data are generally computed by adding together production numbers of particular goods; they depend for their accuracy on reliable component series. Net exports are probably the most accurately measured series because nations collect trade statistics in the process of collecting tariffs. As in modern national accounts, there 
is some variation in the treatment of earnings to foreign capital, which are treated as imports in some cases and omitted in others. Government spending series are also fairly accurate, being based on government records.

Table 3 summarizes the behavior of fluctuations in expenditure components. We see that investment (I) is between two and five times more variable than output for every country and period. Investment is also strongly procyclical. The single exception is prewar Japan, for which measured investment is slightly countercyclical. Among the possible sources of this exceptional behavior is the active participation of government in capital formation. Henry Rosovsky (1961, Table 7) estimates that government accounted for about half of Japanese gross investment prior to World War II. This compares with ten to twenty percent in Australia (Butlin 1962, Tables 5 and 10), eight to ten percent in Canada (Urquhart 1986, Table 2.2), and about five percent in the United States (Kuznets 1961, Table 22). Rosorsky (1961, pp. 29-30) notes that the cyclical properties of government capital formation were governed not by the business cycle, but by natural disasters, military buildups, and a surge in railroad construction in the early part of the twentieth century. This countercyclical pattern is, in any case, reversed after World War I.

Consumption (C) is also uniformly procyclical. The cross-correlation between fluctuations in consumption and output ranges from 0.41 in the prewar United Kingdom to 0.91 in the prewar United States. Its variability is about the same as output's: the ratio of its standard deviation to that of output is close to one in most cases. The exception is postwar Norway, where consumption has been less volatile than investment, but more volatile than output. In postwar data for the United States, consumption is considerably less variable than output if we exclude purchases of consumer durables, but in earlier periods durables are a smaller fraction of personal consumption expenditures and this adjustment is less relevant.

Government spending $(G)$ exhibits little regularity. Its variability, relative to output, ranges from 0.81 in interwar Sweden to 8.72 in interwar Britain to 9.49 in prewar 
Japan. The last figure is due partly to military spending during the Russo-Japanese War. This broad range of experience is not amenable to simple summary, suggesting that at least one aspect of government policy has varied widely over time and across countries. Correlations between government spending and output are equally diverse. Of the 18 estimated cross-correlations, 10 are positive and 8 are negative.

Net exports (NX) is measured, for the purpose of defining fluctuations, as the ratio of current-value net exports to nominal output. Since the ratio is close to zero, its variance and cross-correlation with output can safely be attributed to movements in the numerator - that is, its variability is due primarily to variability in net exports, and its cross-correlation with output reflects the cross-correlation of net exports with output. The standard deviation of fluctuations in this ratio ranges from 0.43 percent in postwar America to 3.47 percent in postwar Norway. Most of the standard deviations fall between 1.0 and 1.6 percent. The United States is, by a wide margin, the country with the least variability in net exports in all three periods. Net exports have generally been countercyclical: in two-thirds of the cases, the cross correlation is negative, often strongly so. In the other cases the correlation is generally small.

Most of these properties are familiar to students of American business cycles. The volatility and procyclicality of durable goods production is cited by Zarnowitz (1985, p. 527), for example, as a long-standing feature of business cycles. Although it is not emphasized, it is also apparent in, among many other places, studies of the interwar period by Burns and Mitchell (1946, Chart 8, series 16-19) and R.A. Gordon (1951, Table 3) using the NBER methodology. In a similar vein, Gordon and John Veitch (1986) note, as we do in Table 3, that U.S. investment is both more variable and more highly correlated with output in the interwar period than it has been since World War II. Table 3 suggests that this change does not generally apply to other countries. More recent work with quarterly postwar data includes Robert King and Charles Plosser (1989) and Kydland and Prescott (1990), both of whom document the procyclical movements in consumption and investment expenditures as well as their relative volatilities. Blackburn 
and Ravn (1991), Brandner and Neusser (1990), Correia, Neves, and Rebelo (1991), and Danthine and Donaldson (1991) verify these properties in postwar data for a variety of other developed countries. Table 3 expands this set of empirical regularities in two directions, to a broader set of countries and a longer period of time.

Countercyclical movements of the trade balance have also been documented in other studies. Ilse Mintz (1959), for example, finds countercyclical movements in the U.S. trade balance in the prewar, interwar, and early postwar periods, just as we report in Table 3. She bases her finding on a comparison of trade balances with the NBER's business cycle chronologies, a methodology quite different from ours. She also finds, by the same method, that in the U.K. trade was procyclical in the prewar period, countercyclical between the wars. We find, however, procyclical movement in both periods. Although there are important differences in data and methodology between our studies, the discrepancy in the interwar period appears to be the result, in large part, of our treatment of the contraction that starts our interwar sample period, 1920-1939. During this contraction the trade balance improved sharply, but in the rest of the interwar period the trade balance is weakly procyclical. By moving the start of our sample period back one year to 1919 we place more emphasis on this event and find, like Mintz, that net exports are countercyclical (the correlation between net exports and output changes from 0.19 to -0.31 ). Finally, we note that the countercyclical tendency of the trade balance is also apparent in quarterly postwar data, including all twelve countries of Backus, Kehoe, and Kydland (1992, Table 2).

In Table 4 we present evidence on another international aspect of business cycles: the contemporaneous correlation between output fluctuations in different countries. Generally speaking, correlations were highest in the interwar period, reflecting the common experience of the 1930s. The exceptions are Germany and Japan, which were largely untouched by the Depression. In the pre- and postwar periods the correlation is typically larger after World War II than before World War I. This is exactly what we would expect if country-specific measurement error were larger in the prewar period, so it 
is not clear how much of this change is real. A comparison by Moore and Zarnowitz (1986, Figure A.1) of business cycle chronologies in Germany, the U.K., and the U.S., indicates that the prewar conformity of cycles across countries is substantial, but even here there are several cycles in the U.S. that are not matched in the other countries. The absence of reliable data makes it difficult to say anything definitive on this point.

\section{Fluctuations in Price Levels and Monetary Aggregates}

We turn to the behavior of price levels and money stocks. Table 5 summarizes the behavior of inflation rates (first differences in the logarithms of price levels). We see, with the notable exception once more of Japan, that price levels changed very little, on average, during the prewar period, declined between the wars, and rose after World War II. The small mean inflation rates before World War I are not, however, indications of price level stability: the standard deviations of inflation rates are comparable to those of the postwar period. The interwar period was even more volatile in this sense, with standard deviations larger than either of the other two periods for each of the ten countries.

Perhaps the most striking change in Table 5 is the sharp increase in the autocorrelation of inflation rates between the prewar and postwar periods. This change has been noted by Gordon (1980, Table 1; 1983, Table 1), Sachs (1980, Table 3), and Schultze (1986, Table 1-1) in estimates of Phillips Curves with U.S. data, and by Sheffrin and Liang-Yn Liu (1990) and Taylor (1986) in bivariate autoregressions of prices and output. Gordon (1983) also examined data for two other countries, concluding that there was a significant postwar increase in persistence in the U.K., but not in Japan. Table 5 indicates that the tendency toward greater persistence in prices after World War II is fairly widespread. In every country but Norway, the autocorrelation of inflation is higher in the postwar period than it was prior to the first world war, and in all but Japan and Sweden the increase is greater than 0.25 .

Properties of price level fluctuations - that is, movements in the logarithms of 
the price level filtered by the Hodrick-Prescott method - are reported in Table 6. As with the autocorrelations of inflation rates, there is a striking difference between the postwar and the earlier periods. In both the prewar and interwar periods, the correlation between price level and output fluctuations is predominantly positive, and for two of the three exceptions the correlation is essentially zero. The only significant outlier is prewar Japan, with a correlation of -0.45 . We know that the price level in prewar Japan varied wildly (the standard deviations of both price fluctuations and inflation rates are the highest of any country in our sample). One explanation, suggested by Rosovsky (1966), is that the prewar experience reflects temporary instability as a national banking system and convertible currency were established. The extreme price level movements between 1885 and 1914 were mild compared with the 60 percent cumulative inflation of 1878-81 and subsequent 25 percent deflation of 1881-84 (see Rosovsky 1966, Tables 9 and 12). The implication is that this experience is unique to prewar Japan, and possibly related to the absence of a metallic standard during the nineteenth century. In most of the other countries in our sample, prices are procyclical in both the prewar and interwar periods, sometimes strongly so.

In the postwar period we see the opposite. Price fluctuations are inversely correlated with output in eight countries, and in the other two countries the correlation is close to zero. The average correlation is -0.36 . If we divide the postwar period in 1968-69, we find that the negative correlation is stronger in the second half. The average correlation falls from -0.27 in the early postwar period to -0.45 later in the period. The correlation is, nevertheless, negative in both subperiods in eight of the ten countries, the exceptions being the same as for the period as a whole: Canada and Germany.

One possibility is that the difference between periods is the result of measurement error in the prewar and interwar periods. Consider, for example, the effect of white noise error in estimates of nominal output. After deflating by the price level, we would expect the same measurement error to appear in estimates of real output. But there is no reason to believe that these errors would be positively correlated with prices 
and thus lead to a positive correlation between prices and output. Alternatively, suppose white noise errors are present in estimated price indexes. Since real output is generally estimated as the ratio of nominal output to a price index, we would expect to see measurement error of the opposite sign in real output. If anything this should lead prices and output to appear more countercyclical than they are. Thus we think it is unlikely that measurement error would lead us to conclude incorrectly that prices are procyclical.

A direct indication of the effect of measurement error on the price/output correlation is available for the United States. Balke and Gordon (1989) argue that one weakness of the traditional Kuznets-based estimates of real GNP is the price deflator. They report a revised series based on several decades of careful research into historical price data and make a persuasive case that their series is substantially more accurate than the traditional one. Using their price series, we find that the standard deviation of price level fluctuations in the prewar period falls from 3.04 to 1.62 percent, so the two series clearly differ in their cyclical properties. When we examine the relation of their series to output, we find that the correlation rises, as expected, from 0.22 to 0.42 . Measurement error in price levels should also lower measured autocorrelations. We find that the autocorrelation of inflation for the Balke-Gordon (1989) series is 0.31 , which is indeed greater than the autocorrelation of 0.17 reported in Table 5. The difference, however, is too small to account for the difference in persistence between the prewar and postwar periods.

Similar countercyclical movements in the price level have been reported in other studies of postwar data using similar methods, including Thomas Cooley and Gary Hansen (1989), Kydland and Prescott (1990), and Holger Wolf (1991) for the United States, Brandner and Neusser (1990) for Austria and Germany, and Correia, Neves, and Rebelo (1991) for Portugal. Allan Meltzer (1986, Table 4) reports negative correlations between price and output innovations in quarterly postwar data for Canada, Germany, the U.K., and the U.S. Our findings also agree, for the most part, with those of Milton Friedman and Anna Schwartz's (1982, ch. 9) study of the United States and the United 
Kingdom. They report (in Table 9.1) correlations between "phase rates of change" of prices and output, computed as follows. NBER reference dates for business cycle peaks and troughs are used to divide the sample into expansion and contraction phases. For each phase they compute the average logarithm of the price level and output. The phase rate of change is then the weighted average rate of change for three successive phases; see their discussion in Chapter 3. This method is clearly different from ours, but seems closer to the correlations of Table 5 than the fluctuations of Table 6 . With the exception of prewar Britain, their correlations are similar to ours, both in sign and magnitude. In the prewar U.K. they find that prices are countercyclical while we find them slightly procyclical. This difference appears to result as much from differences in the underlying price and output data as from differences in methodology. If we use their data (Columns 3 and 4 of Table 4.9), we find that the correlation between growth rates of prices and output changes from 0.11 to -0.23 , which is reasonably close to their correlation of -0.33 for phase rates of change. Friedman and Schwartz use, essentially, Feinstein's (1972) income-based estimate of GNP, minus capital consumption. When we use other income-based estimates of real output, even Greasley's (1989) revised estimate, we too find that inflation and output growth are inversely correlated. The issue, then, is which estimate of British output is the most reliable. We suggested earlier that Feinstein's compromise estimate, which we use throughout, is probably the most accurate, which implies that the correlation between growth rates of prices and output in prewar Britain is probably positive, and almost certainly small.

Changes in the persistence of inflation and in the sign of the correlation between price and output fluctuations are the most striking differences between periods in the variables we have studied, and contrast sharply with the regularity in the comovements of real quantities. In Tables 7 and 8 we report analogous properties of broad monetary aggregates, typically M2 or M3, compiled by Michael Bordo and Jonung (1987). We find, in Table 7, that there has been no obvious temporal pattern in the autocorrelation of money growth rates. The autocorrelation fell between the prewar and 
postwar periods by at least 0.25 in three countries, rose by at least 0.25 in three others, and changed by less than 0.25 in the rest. The interwar autocorrelations exhibit little resemblance to either of the other two periods. In Table 8 , we find a modest tendency toward lower correlation between money and output fluctuations in the postwar period. The mean correlation declines from 0.33 prewar and 0.31 interwar to 0.20 postwar. But we do not see, for the most part, the same changes in the behavior of money that we saw in prices. This finding augments earlier work for the U.S. and U.K. Phillip Cagan (1965, pp. 4-7) reports, for example, that money growth in the U.S. was consistently countercyclical from 1871 to 1960, the only exceptions occurring during the 1940s. Friedman and Schwartz (1982, Table 9.1) find, as we do, that phase rates of change in money and output were positively correlated in the U.S. in all three periods, though only slightly so in the postwar period. For the U.K. they verify that money and output are positively correlated in the prewar period, negatively correlated between the wars. But while we find that the money stock is procyclical in the postwar period, they report countercyclical movements. In this case the discrepancy is due almost entirely to differences in method: when we apply our methods to their data, we find that the correlations with output are very close to what we report in Tables 7 and 8.

Thus we have found, for most of the countries in our sample, that since the second world war inflation rates have become more persistent and price fluctuations have changed from procyclical to countercyclical. Although our objective is to document properties of aggregate data, not explain them, we find it difficult to resist speculation on the source of these shifts in the behavior of prices. Roughly speaking, one might attribute such shifts either to changes in the economic environment (the impulses) or to changes in the economic structure (the propagation mechanism). Examples of each have appeared in the literature. One hypothesis, implicit in Gordon $(1980,1983)$, is that we can account for the changing cyclical behavior of prices in an aggregate supply and demand framework with a combination of increased persistence in inflation and greater variability of "supply shocks" in the postwar period. In his view, the dramatic increase in the autocorrelation of 
inflation is a change in economic structure that helps to account for the shift in the cyclical behavior of prices.

An alternative hypothesis is provided by Cagan (1986, p. 664), who suggests that increased inflation persistence may be the result of postwar changes in policy: that there has been, in his words, "a general expectation that government policies will oppose severe price movements... [which] shows up in the time series as autocorrelation and greater persistence." With respect to the relation between prices and output, he suggests that "the monetary authority did not accommodate price movements in the later period but did so in the earlier period." This explanation is echoed by Bordo (1990), who notes that monetary policy was much different under the gold standard than it has been in the postwar period. The exceptional behavior of prewar Japan is, in his view, further evidence for this interpretation, since Japan was one of the few countries in our sample not on the gold standard during most of the prewar period. Schultze (1986, Lecture III) and Taylor (1986) apparently concur, arguing that the gold standard was characterized in the United States by substantial short-term monetary accommodation.

We leave the resolution of this issue to others. What we have shown is that the changing behavior of prices has been, in large part, an international phenomenon, and will therefore require an explanation that cuts across national boundaries.

\section{Concluding Remarks}

We have studied national income, expenditure components, price levels, and money stocks and found that business cycles before World War II share many features with those of the postwar period. The most striking changes over the last hundred years concern the behavior of price levels. We find in most of the countries we study that inflation rates are significantly more persistent in the postwar period, and that prices are

generally procyclical prior to World War II, countercyclical afterwards. Both the similarities across countries and the changes over time should provide impetus and direction to theories of aggregate fluctuations. 


\section{Appendix A: Data Sources and Definitions}

In the following pages we describe our data sources in enough detail that one could, at least in principle, replicate the entire study. In addition, the data (in RATS, TROLL, and Lotus formats) and computer programs (written in RATS and GAUSS) are available at marginal cost from the authors. Some of the series are available in Mitchell (1976) and Angus Maddison (1982). But for the most part we went to original sources or compilations of data for specific countries. The major exception is the postwar period, for which we relied on the International Monetary Fund's International Financial Statistics, hereafter IFS, the July 1987 computer tape in particular. Monetary aggregates are taken from worksheets provided by Bordo, from his book with Jonung (1987), and from Friedman and Schwartz (1982).

The variables were constructed according to a few simple principles. Output numbers are real GDP or GNP, depending on which was more commonly used in each country. Splices between two series were accomplished by multiplying the earlier series by a constant, chosen so that both series take the same value at the splice point. With this method growth rates are never computed across different series. Expenditure series are deflated by their own deflators where possible and the output deflator otherwise, and spliced in the same way. The ratio of net exports to output is a ratio of nominal magnitudes. If there is more than one output series, we use the series from the same source as net exports to form the ratio. No splicing was done for the ratio.

Specific sources follow.

Australia. The basic sources are N. G. Butlin (1962) [ADP], M. W. Butlin (1977) [MWB], and IFS. Some of MWB has been reprinted in Maddock and McLean (1987), Statistical Appendix.

GDP. 1861-1900: ADP, table 13. 1901-48: MWB, table IV.1 divided by the deflator from table IV.2. 1949-86: IFS, series 99b.r.

Investment. 1861-1900: ADP, table 13. 1901-48: MWB, Tables IV.1 and 
IV.2. 949-86: IFS, series 93e divided by the GDP deflator.

Net exports. 1861-1900: ADP, table 247, series 11, minus table 248, series 1 and 10. 1901-48: MWB, table IV.1. 1949-86: IFS, series 90c minus 98c.

Price level. 1861-1900: ADP, table 13. 1901-48: MWB, table IV.2. 1949-86: IFS, implicit GDP deflator, series $99 \mathrm{~b}$ divided by $99 \mathrm{~b} . \mathrm{r}$.

Money stock. 1870-1970: M2, Bordo-Jonung worksheets.

Canada. The sources are Urquhart (1986), which begins with Canadian confederation in 1871, and Statistics Canada's CANSIM University Base (1986).

GNP. 1871-1925: Urquhart, table 2.9. 1926-83: CANSIM, series D40646.

Investment. 1871-1925: Urquhart, table 2.2, divided by the GNP deflator from table 2.9. 1926-83: CANSIM, series D30016, divided by GNP deflator implicit in series D30013 and D40646.

Government purchases. 1871-1925: Urquhart, table 2.3. 1926-83: CANSIM, series D30015 and D30017.

Net exports. 1871-1925: Urquhart, table 2.4. 1926-83: CANSIM, series D30029 minus D30030.

Price level. 1871-1925: Urquhart, table 2.9. 1926-83: CANSIM, series 30013 divided by $\mathrm{D} 40646$.

Money stock. 1871-1975, M2, Bordo-Jonung worksheets.

Denmark. The sources are Mitchell (1976) [EHS] and IFS, and the data ranges from 1870 to 1985 , with a gap from 1915 to 1920 .

GNP and GDP. 1870-1947: GNP, EHS, table K1. 1948-85: GDP, IFS, series 99b.p.

Investment. 1870-1947: EHS, table K1. 1948-85: IFS, series 93e divided by the GDP deflator.

Price level. 1870-1947: EHS, table K1, implicit price deflator. 1948-85: IFS, implicit GDP deflator, series 99b divided by 99b.p.

Money stock. 1871-1975, M2, Bordo-Jonung worksheets. 
Germany. The sources are Mitchell (1976) [EHS] and IFS, and the data covers the periods 1850-1913, 1925-38, and 1950-86.

NNP and GNP. 1850-1913, 1925-38: NNP, EHS, table K1. 1950-86: GNP, IFS, series 99a.r.

Price level. 1850-1913, 1925-38: EHS, table K1, implicit price deflators. 1950-86: IFS, implicit GDP deflator, series 99a.c divided by 99a.r.

Money stock. 1870-1970: M2, Bordo-Jonung worksheets.

Italy. The sources are Mitchell (1976) [EHS] and IFS.

GNP and GDP. 1861-1949: GNP, EHS, table K1. 1950-86: GDP, IFS, series 99b.r.

Investment. 1861-1949: EHS, table K1. 1950-86: IFS, series 93e divided by the GDP deflator.

Price level. 1861-1949: EHS, table K1, implicit price deflator. 1950-86: IFS, implicit GDP deflator, series $99 \mathrm{~b}$ divided by $99 \mathrm{~b} . \mathrm{r}$.

Money stock. 1870-1975: Bordo-Jonung worksheets.

Japan. The sources are Ohkawa, Takamatsu, and Yamamoto (1974) [LTES] and IFS. The sample periods are 1885-1940 and 1952-85.

GNP. 1885-1940: LTES, table 18. 1952-85: IFS, series 99a.r.

Consumption. 1885-1940: LTES, table 18. 1952-85: IFS, series $96 \mathrm{f}$ divided by the GNP deflator.

Investment. 1885-1940: LTES, table 18. 1952-85: IFS, series 93e divided by the GNP deflator. Additional data from LTES, table 4.

Government purchases. 1885-1940: LTES, table 18. 1952-85: IFS, series $91 f$ divided by the GNP deflator.

Net exports. 1885-1940: LTES, table 1. 1952-85: IFS, series 93c minus 98c.

Price level. 1885-1940: LTES, implicit output deflator from tables 1 and 18. 1952-85: IFS, series 99a divided by 99a.r.

Money stock. 1885-1962: Bordo-Jonung worksheets. 
Norway. The sources are the Norwegian Central Bureau of Statistics (1965) [NA] and IFS. The sample period is 1865-1986, with a gap from 1940 to 1945.

GDP. 1865-1949: NA, table 51. 1950-86: IFS, series 99b.p.

Consumption. 1865-1949: NA, table 51. 1950-86: IFS, series $96 \mathrm{f}$ divided by the GDP deflator.

Investment. 1865-1949: NA, table 51. 1950-86: IFS, series 93e divided by the GDP deflator.

Government purchases. 1865-1949: NA, table 51. 1950-86: IFS, series $91 \mathrm{f}$ divided by the GDP deflator.

Net exports. 1865-1949: NA, table 51. 1950-86: IFS, series 90c minus 98c.

Price level. 1865-1949: NA, table 52. 1950-86: IFS, series 99b divided by 99b.p.

Money stock. 1870-1974: Bordo-Jonung worksheets.

Sweden. The sources are Johansson (1967), Krantz and Nilsson (1975) [KN], and IFS.

GDP. 1861-1949: KN, table 1.1. 1950-86: IFS, series 99b.p. The Johansson series referred to in the text is from table 56.

Consumption. 1861-1949: Johansson, table 57, divided by the GDP deflator. 1950-86: IFS, series $96 \mathrm{f}$, divided by the GDP deflator.

Investment. 1861-1949: Johansson, table 57, divided by the GDP deflator. 1950-86: IFS, series 93e, divided by the GDP deflator.

Government purchases. 1861-1949: Johansson, table 57, divided by the GDP deflator. 1950-86: IFS, series 91f, divided by the GDP deflator.

Net exports. 1861-1949: Johansson, table 57, divided by the GDP deflator. 1950-86: IFS, series 93e, divided by the GDP deflator.

Price level. 1861-1949: Johansson, implicit GDP deflator from tables 56 and 57. 1950-86: IFS, series $99 \mathrm{~b}$ divided by $99 \mathrm{~b} . \mathrm{p}$.

Money stock. 1871-1975: Bordo-Jonung worksheets.

United Kingdom. The sources are Feinstein (1972) and IFS. An additional output series 
is taken from Greasley (1989).

GDP. 1855-1947: compromise estimate from Feinstein, table 6. 1948-86: IFS, series 99b.p. Feinstein's income, expenditure, and output estimates are also from table 6 (the unadjusted versions). The Greasley series is reported in his appendix table 2.

Consumption. 1870-1947: Feinstein, table 7. 1948-86: IFS, series $96 \mathrm{f}$ divided by the GDP deflator.

Investment. 1870-1947: Feinstein, table 7. 1948-86: IFS, series 93e divided by the GDP deflator.

Government purchases. 1870-1947: Feinstein, table 7. 1948-86: IFS, series $91 f$ divided by the GDP deflator.

Net exports. 1870-1947: Feinstein, table 2. 1948-86: IFS, series 90c minus $98 \mathrm{c}$.

Price level. 1870-1947: Feinstein, table 61, series 7. IFS, series $99 \mathrm{~b}$ divided by 99b.p.

Money stock. 1871-1975: Friedman and Schwartz, table 4.9.

United States. The basic sources are Balke and Gordon (1986) [BG], John Kendrick (1961), and the Board of Governors of the Federal Reserve System database [Board]. Additional sources of output and price level data are Romer (1989) and Balke and Gordon (1989) [BG89].

GNP. 1869-1983: BG, table 1. Additional series from Romer, table 2, and BG89, table 10 .

Consumption. 1889-1929: Kendrick, table A-IIa. 1930-86: Board.

Investment. 1889-1929: Kendrick, table A-IIa. 1930-86: Board.

Government purchases. 1889-1929: Kendrick, table A-IIa. 1930-86: Board.

Net exports. 1889-1929: Kendrick, table A-IIb. 1930-86: Board.

Price level. 1869-1983: BG, table 1. Additional series from BG89, table 10.

Money stock. 1869-1975: Friedman and Schwartz, table 4.8. 


\section{Appendix B: The Hodrick-Prescott Filter}

The Hodrick-Prescott filter, described by Robert Hodrick and Prescott (1980) and Kydland and Prescott (1990), defines a trend $\left\{\tau_{t}\right\}$ for a series $\left\{\mathrm{y}_{t}\right\}$ as the solution to the problem

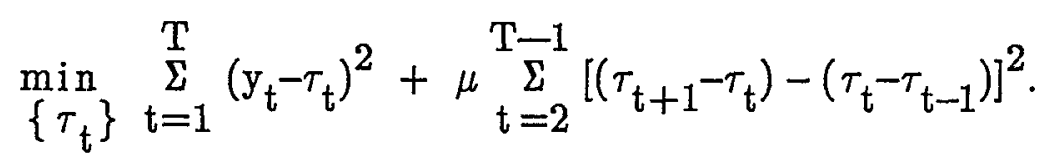

Fluctuations are defined as deviations from trend, $\mathrm{y}_{t}-\tau_{\mathrm{t}}$. We use $\mu=100$ in all tables concerning fluctuations of variables. A procedure for computing the trend is available in RATS as file HPFILTER.SRC; an equivalent FORTRAN subroutine is available from the authors. 


\section{References}

Backus, David, and Kehoe, Patrick, "Trade and Exchange Rates in a Dynamic Competitive Economy," Federal Reserve Bank of Minneapolis Working Paper 348, April 1987.

Backus, David, Kehoe, Patrick and Kydland, Finn, "International Real Business Cycles," Journal of Political Economy, forthcoming 1992.

Baily, Martin, "Stabilization Policy and Private Economic Behavior," Brookings Papers on Economic Activity, 1978, 11-50.

Balke, Nathan, and Gordon, Robert, "Appendix B: Historical Data," in R. Gordon, ed., The American Business Cycle: Continuity and Change, Chicago: University of Chicago Press, 1986.

Balke, Nathan, and Gordon, Robert, "The Estimation of Prewar Gross National Product: Methodology and New Evidence," Journal of Political Economy, February $1989,97,38-92$.

Bergman, Michael, and Jonung, Lars, "Has the business cycle been dampened? The case of Sweden and the United States, 1873-1988," mimeo, Stockholm School of Economics, June 1989.

Bjerke, Kjeld, "The National Product of Denmark, 1870-1952," Income and Wealth, Series V, London: Bowes and Bowes, 1955.

Blackburn, Keith, and Ravn, Morten, "Contemporary Macroeconomic Fluctuations: An International Perspective," University of Southampton Discussion Paper No. 9106, January 1991.

Boehm, E.A., Prosperity and Depression in Australia 1887-1897, Oxford: Clarendon Press, 1971.

Bordo, Michael, Private communication, 1990.

Bordo, Michael, and Jonung, Lars, The Long-Run Behavior of the Velocity of Circulation, Cambridge: Cambridge University Press, 1987. 
Brandner, Peter, and Neusser, Klaus, "Business Cycles in Open Economies: Stylized Facts for Austria and Germany," mimeo, Vienna, May 1990.

Burns, Arthur, "Progress Towards Economic Stability," American Economic Review, March 1960, 50, 1-19.

Burns, Arthur, and Mitchell, Wesley, Measuring Business Cycles, New York: National Bureau of Economic Research, 1946.

Butlin, M. W., "A Preliminary Annual Database 1900/01 to 1973/74," Research Discussion Paper 7701, Reserve Bank of Australia, May 1977.

Butlin, N. G., Australian Domestic Product, Investment, and Borrowing, 1861-1938/39, Cambridge: Cambridge University Press, 1962.

Cagan, Phillip, Determinants and Effects of Changes in the Stock of Money, 1875-1960, New York: Columbia University Press, 1965.

Cagan, Phillip, "Comment on Taylor," in R. Gordon, ed., The American Business Cycle: Continuity and Change, Chicago: University of Chicago Press, 1986.

Christiano, Lawrence, and Eichenbaum, Martin, "Current Real Business Cycle Theories and Aggregate Labor Market Fluctuations," American Economic Review, forthcoming 1992 .

Cooley, Thomas, and Hansen, Gary, "The Inflation Tax in a Real Business Cycle Model," American Economic Review, September 1989, 79, 733-748.

Correia, Isabel, Neves, Joao, and Rebelo, Sergio, "Business Cycles in Portugal: Theory and Evidence," mimeo, Banco de Portugal, February 1991.

Danthine, Jean-Pierre, and Donaldson, John, "Methodological and Empirical Issues in Real Business Cycle Theory," European Economic Review, forthcoming 1991.

Feinstein, Charles, National Income, Expenditure, and Output of the United Kingdom, 1855-1965, Cambridge: Cambridge University Press, 1972.

Friedman, Milton, and Schwartz, Anna, Monetary Trends in the United States and the United Kingdom, Chicago: University of Chicago Press, 1982.

Gallman, Robert, "GNP in the United States, 1834-1909," in Output, Employment, and 
Productivity in the United States after 1800, Studies in Income and Wealth, vol. 30. New York: National Bureau of Economic Research, 1966.

Gordon, R. A., "Cyclical Experience in the Interwar Period: The Investment Boom of the Twenties," in Conference on Business Cycles, New York: National Bureau of Ecònomic Research, 1951.

Gordon, Robert, "A Consistent Characterization of a Near-Century of Price Behavior," American Economic Review, May 1983, 79, 243-249.

Gordon, Robert, "A Century of Evidence on Wage and Price Stickiness in the United States, the United Kingdom, and Japan," in J. Tobin, ed., Macroeconomics, Prices, and Quantities, Washington: Brookings Institution, 1983.

Gordon, Robert, and Veitch, John, "Fixed Investment in the American Business Cycle, 1919-83," in R. Gordon, ed., The American Business Cycle: Continuity and Change. Chicago: University of Chicago Press, 1986.

Greasley, David, "British Wages and Income, 1856-1913: A Revision," Explorations in Economic History, April 1989, 26, 237-247.

Hansen, S-Aa, Oekonomisk vaekst i Danmark, vol. II, Copenhagen: Institute of Economic History, 1974.

Hodrick, Robert, and Prescott, Edward, "Postwar U.S. Business Cycles: An Empirical Investigation," mimeo, Carnegie Mellon University, November 1980.

International Monetary Fund, International Financial Statistics (magnetic tape), Washington, 1987.

Jefferys, James, and Walters, Dorothy, "National Income and Expenditure of the United Kingdom," in Income and Wealth, Series V, London: Bowes and Bowes, 1955.

Johansson, Osten, The GDP of Sweden and its Composition, 1861-1955, Stockholm: Almqvist and Wiksell, 1967.

Jostock, Paul, "The Long-Term Growth of National Income in Germany," in Income and Wealth; Series V, London: Bowes and Bowes, 1955. 
Kendrick, John, Productivity Trends in the United States, Princeton: Princeton University Press, 1961.

King, Robert, and Plosser, Charles, "Real Business Cycles and the Test of the Adelmans," mimeo, University of Rochester, February 1989.

Krantz, Olle, "New Estimates of Swedish Historical GDP Since the Beginning of the Nineteenth Century," Review of Income and Wealth, 1989, 165-181.

Krantz, Olle, and Nilsson, Carl-Axel, Swedish National Product, 1861-1970, Lund: Gleerup, 1975.

Kuznets, Simon, Capital in the American Economy. Princeton: Princeton University Press, 1961.

Kydland, Finn, and Prescott, Edward, "Business Cycles: Real Facts and a Monetary Myth," Federal Reserve Bank of Minneapolis Quarterly Review, Spring 1990.

Lindahl, Eric, Dahlgren, Einar, and Kock, Karin, National Income of Sweden, 1861-1930, Volume III of Wages, Cost of Living and National Income of Sweden, 1861-1930, London: P.S. King and Sons, 1937.

Lucas, Robert, "Understanding Business Cycles," in K. Brunner and A. Meltzer, eds., Stabilization of the Domestic and International Economy, Carnegie-Rochester Conference Series 5, Amsterdam: North-Holland, 1977.

Maddison, Angus, Phases of Capitalist Development, Oxford: Oxford University Press, 1982.

Maddock, Rodney, and McLean, Ian, "The Australian Economy in the Very Long Run," in R. Maddock and I. McLean, The Australian Economy in the Long Run, Cambridge: Cambridge University Press, 1987.

Meltzer, Allan, "Size, Persistence and Interrelation of Nominal and Real Shocks: Some Evidence From Four Countries," Journal of Monetary Economics, January 1986, $17,161-194$.

Mintz, Ilse, Trade Balances During Business Cycles: United States and Britain Since 1980, New York: National Bureau of Economic Research, Occasional Paper 67, 
1959.

Mitchell, B.R., European Historical Statistics, 1750-1970, New York: Columbia University Press, 1976.

Moore, Geoffrey, and Zarnowitz, Victor, "Appendix A: The Development of the NBER's Business Cycle Chronologies," in R. Gordon, ed., The American Business Cycle: Continuity and Change, Chicago: University of Chicago Press, 1986.

Ohkawa, Kazushi, with Shinohara, M., Umemura, M., Ito, M., and Noda, T., The Growth Rate of the Japanese Economy Since 1878, Tokyo: Kinokuniya, 1957.

Ohkawa, Kazushi, Takamatsu, Nobukiyo, and Yamamoto, Yuzo, Estimates of Long-Term Economic Statistics of Japan Since 1868, vol. 1: National Income, Tokyo: Toyo Keizai Shiposha, 1974.

Prest, A.R., "National Income in the United Kingdom, 1870-1946," Economic Journal March 1948, 58, 31-62.

Romer, Christina, "Is the Stabilization of the Postwar Economy a Figment of the Data?" American Economic Review, June 1986, 76, 314-34.

Romer, Christina, "The Prewar Business Cycle Reconsidered: New Estimates of GNP, 1869-1908," Journal of Political Economy, February 1989, 97, 1-37.

Rosovsky, Henry, Capital Formation in Japan, New York: Free Press, 1961.

Rosovsky, Henry, "Japan's Transition to Modern Economic Growth, 1868-1885," in H. Rosovsky, ed., Industrialization in Two Systems. New York: Wiley, 1966.

Sachs, Jeffrey, "The Changing Cyclical Behavior of Wages and Prices: 1890-1976," American Economic Review, March 1980, 70, 78-90.

Schultze, Charles, Other Times, Other Places: Macroeconomic Lessons from U.S. and European History, Washington: Brookings Institution, 1986.

Shaw, William, Value of Commodity Output Since 1869, New York: National Bureau of Economic Research, 1947.

Sheffrin, Steven, "Have Economic Fluctuations Been Dampened? A Look at Evidence Outside the United States," Journal of Monetary Economics, January 1988, 21, 
$73-83$.

Sheffrin, Steven, and Liu, Liang-Yn, "Cross-Country Comparisons of Historical Changes in Inflation-Output Relations," Journal of Macroeconomics, Winter 1990, 12, 47-64.

Taylor, John, "Improvements in Macroeconomic Stability: The Role of Wages and Prices," in R. Gordon, ed., The American Business Cycle: Continuity and Change. Chicago: University of Chicago Press, 1986.

Tobin, James, Asset Accumulation and Economic Activity, Chicago: University of Chicago Press, 1980.

Urquhart, M. C., "New Estimates of GNP, Canada, 1870-1926: Some Implications for Canadian Development," in S. Engerman and R. Gallman, eds., Long-Term Factors in American Economic Growth, Chicago: University of Chicago Press, 1986.

Wolf, Holger, "Procyclical Prices: A Demi-Myth?" Federal Reserve Bank of Minneapolis Quarterly Review, Spring 1991.

Zarnowitz, Victor, "Recent Work on Business Cycles in Historical Perspective: A Review of Theories and Evidence," Journal of Economic Literature, September $1985,23,523-580$.

Norway, Central Bureau of Statistics, National Accounts, 1865-1960, Oslo: Norwegian Official Statistics XII 163, 1965.

Norway, Central Bureau of Statistics, Historical Statistics, 1978, Oslo: Norwegian Official Statistics XII 291, 1978.

Statistics Canada, CANSIM University Data Base (magnetic tape), Ottawa, 1986. 


\section{INITIAL FOOTNOTE}

*David K. Backus, Stern School of Business, New York University, 100 Trinity Place, New York NY 10006; Patrick J. Kehoe, Federal Reserve Bank of Minneapolis, 250 Marquette Ave., Minneapolis MN 55480, and Department of Economics, University of Minnesota, Minneapolis MN 55455. We thank the many people who helped us find data and made comments on earlier drafts, including Michael Bordo, Phillip Cagan, V.V. Chari, Alan Green, Lars Jonung, Kent Kimbrough, Finn Kydland, Ross Milbourne, Anna Schwartz, Christopher Sims, Gregor Smith, two referees, and especially Edward Prescott, who suggested this line of work. We also thank the National Science Foundation for financial support. The views expressed are those of the authors and not necessarily those of the Federal Reserve Bank of Minneapolis or the Federal Reserve System. 


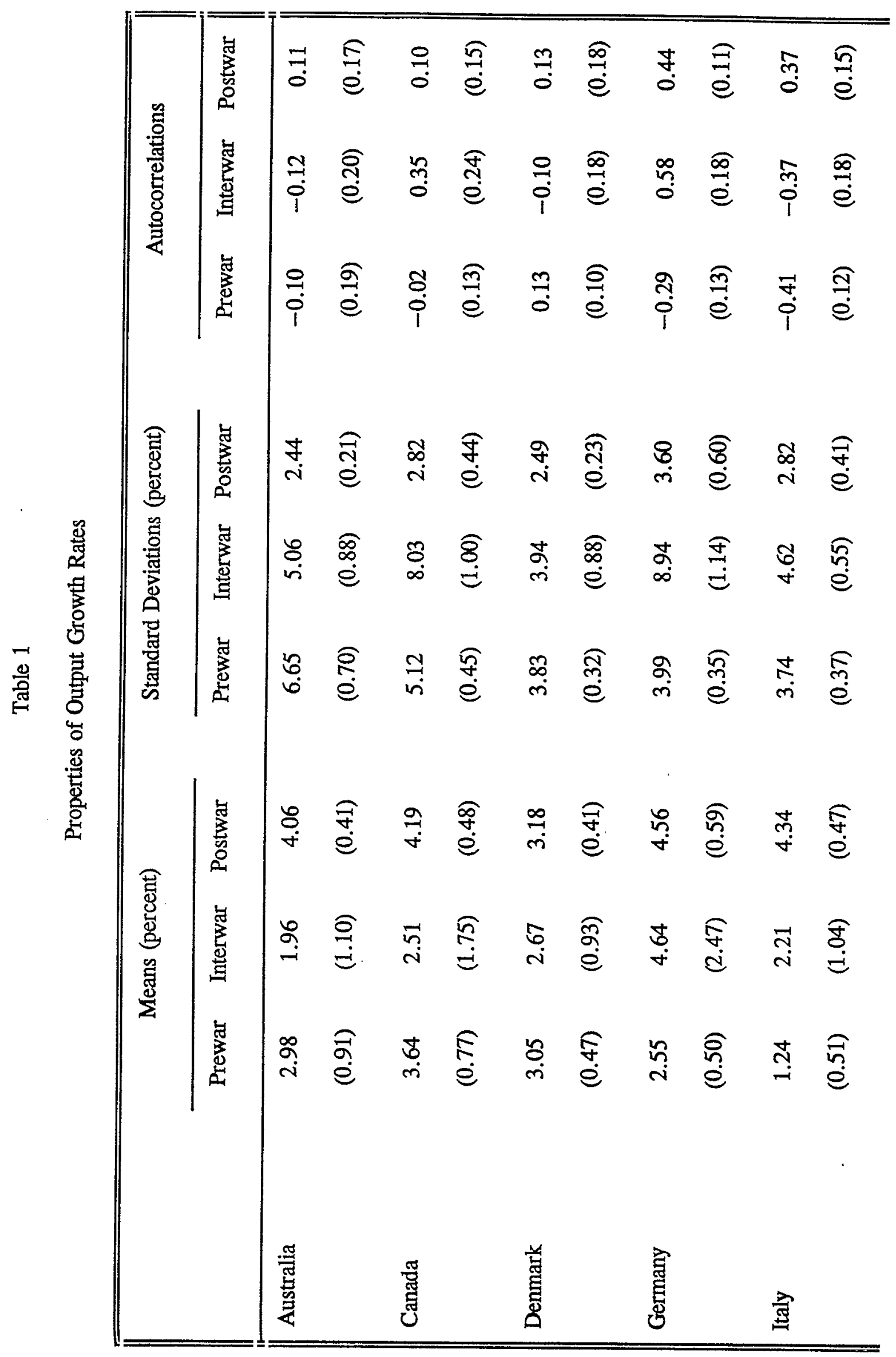




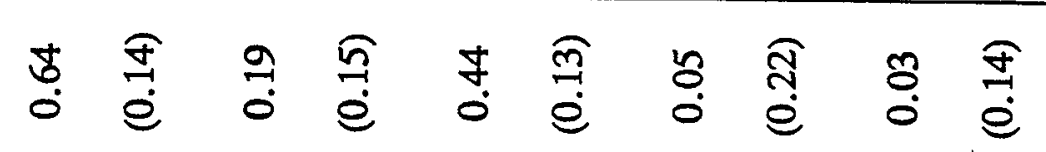

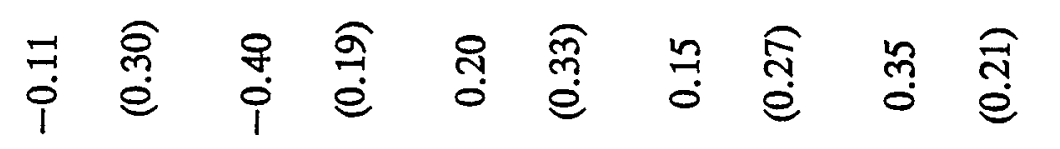

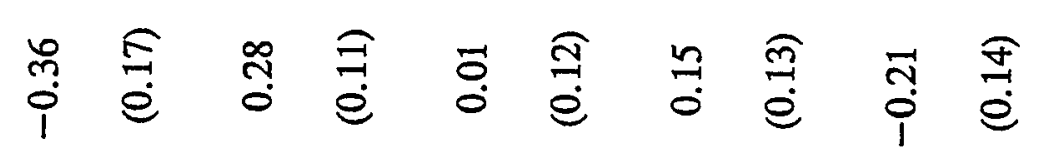

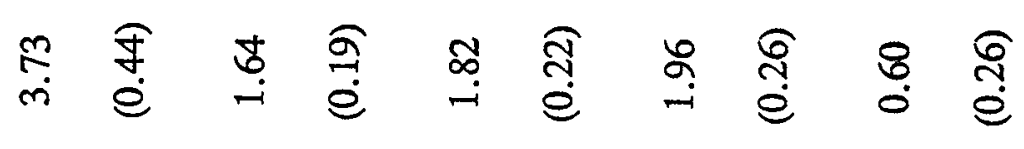

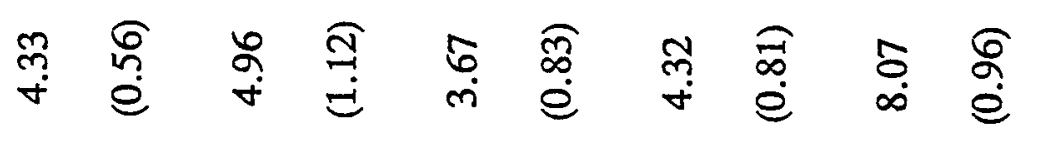

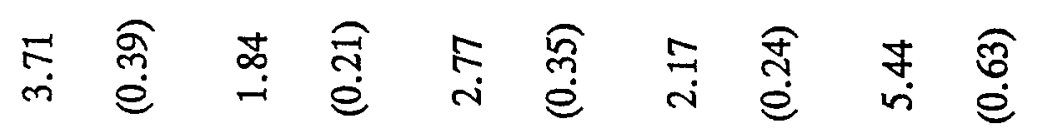

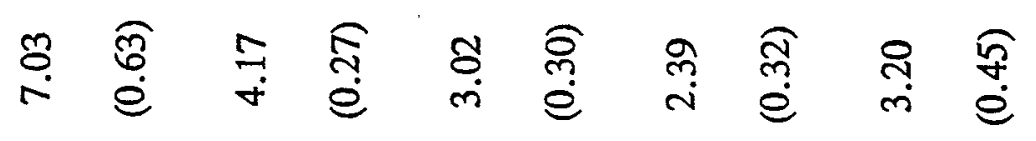

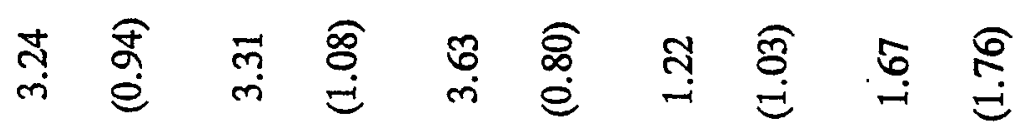

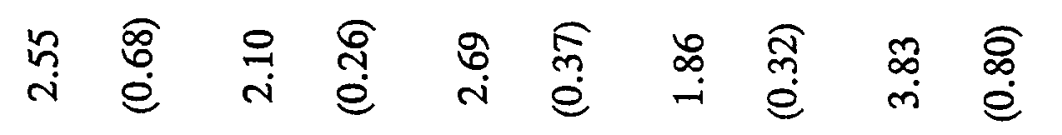

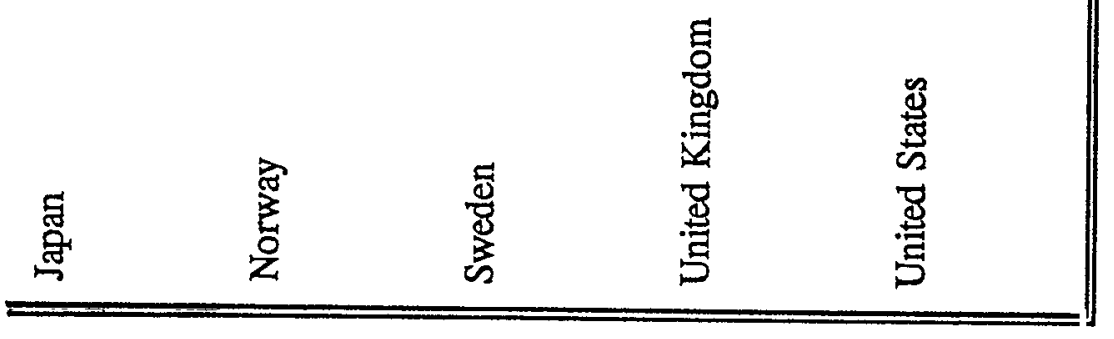

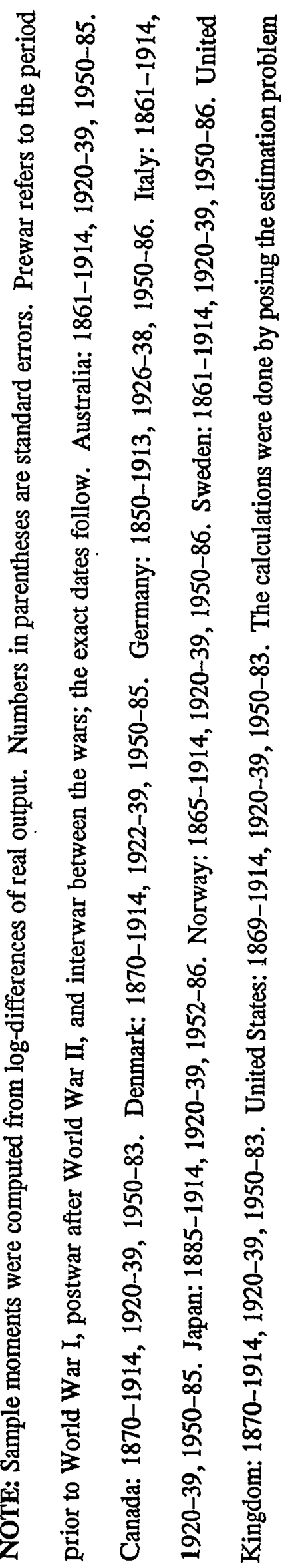




$$
\mid
$$


Table 2

Properties of Output Fluctuations

\begin{tabular}{|c|c|c|c|c|c|}
\hline & \multicolumn{3}{|c|}{ Standard Deviations (percent) } & \multicolumn{2}{|c|}{ Relative to Postwar } \\
\hline & Prewar & Interwar & Postwar & Prewar & Interwar \\
\hline \multirow[t]{2}{*}{ Australia } & 6.30 & 4.85 & 1.93 & 3.3 & 2.5 \\
\hline & $(0.72)$ & $(0.75)$ & $(0.19)$ & & \\
\hline \multirow[t]{2}{*}{ Canada } & 4.47 & 9.80 & 2.22 & 2.0 & 4.4 \\
\hline & $(0.43)$ & $(1.40)$ & $(0.23)$ & & \\
\hline \multirow[t]{2}{*}{ Denmark } & 3.02 & 3.41 & 1.88 & 1.6 & 1.8 \\
\hline & $(0.22)$ & $(0.64)$ & $(0.20)$ & & \\
\hline \multirow[t]{2}{*}{ Germany } & 3.35 & 10.19 & 2.30 & 1.5 & 4.4 \\
\hline & $(0.32)$ & $(1.61)$ & $(0.28)$ & & \\
\hline \multirow[t]{2}{*}{ Italy } & 2.52 & 3.59 & 2.05 & 1.2 & 1.8 \\
\hline & $(0.24)$ & $(0.46)$ & $(0.17)$ & & \\
\hline \multirow[t]{2}{*}{ Japan } & 2.42 & 3.13 & 3.11 & 0.8 & 1.0 \\
\hline & $(0.24)$ & $(0.44)$ & $(0.32)$ & & \\
\hline \multirow[t]{2}{*}{ Norway } & 1.85 & 3.49 & 1.76 & 1.1 & 2.0 \\
\hline & $(0.16)$ & $(0.65)$ & $(0.17)$ & & \\
\hline \multirow[t]{2}{*}{ Sweden } & 2.43 & 3.74 & 1.45 & 1.7 & 2.6 \\
\hline & $(0.37)$ & $(0.59)$ & $(0.12)$ & & \\
\hline
\end{tabular}




\begin{tabular}{|c|c|c|c|c|c|}
\hline United Kingdom & $\begin{array}{l}2.12 \\
(0.24)\end{array}$ & $\begin{array}{c}3.47 \\
(0.37)\end{array}$ & $\begin{array}{l}1.62 \\
(0.21)\end{array}$ & 1.3 & 2.1 \\
\hline United States & $\begin{array}{r}4.28 \\
(0.38)\end{array}$ & $\begin{array}{c}9.33 \\
(1.27)\end{array}$ & $\begin{array}{l}2.26 \\
(0.18)\end{array}$ & 1.9 & 4.1 \\
\hline
\end{tabular}

NOTE: Sample moments were computed from Hodrick-Prescott filtered logarithms of real output. Numbers in parentheses are standard errors, computed by GMM as described in the notes to Table 1. Sample periods are also reported in the notes to Table 1. 


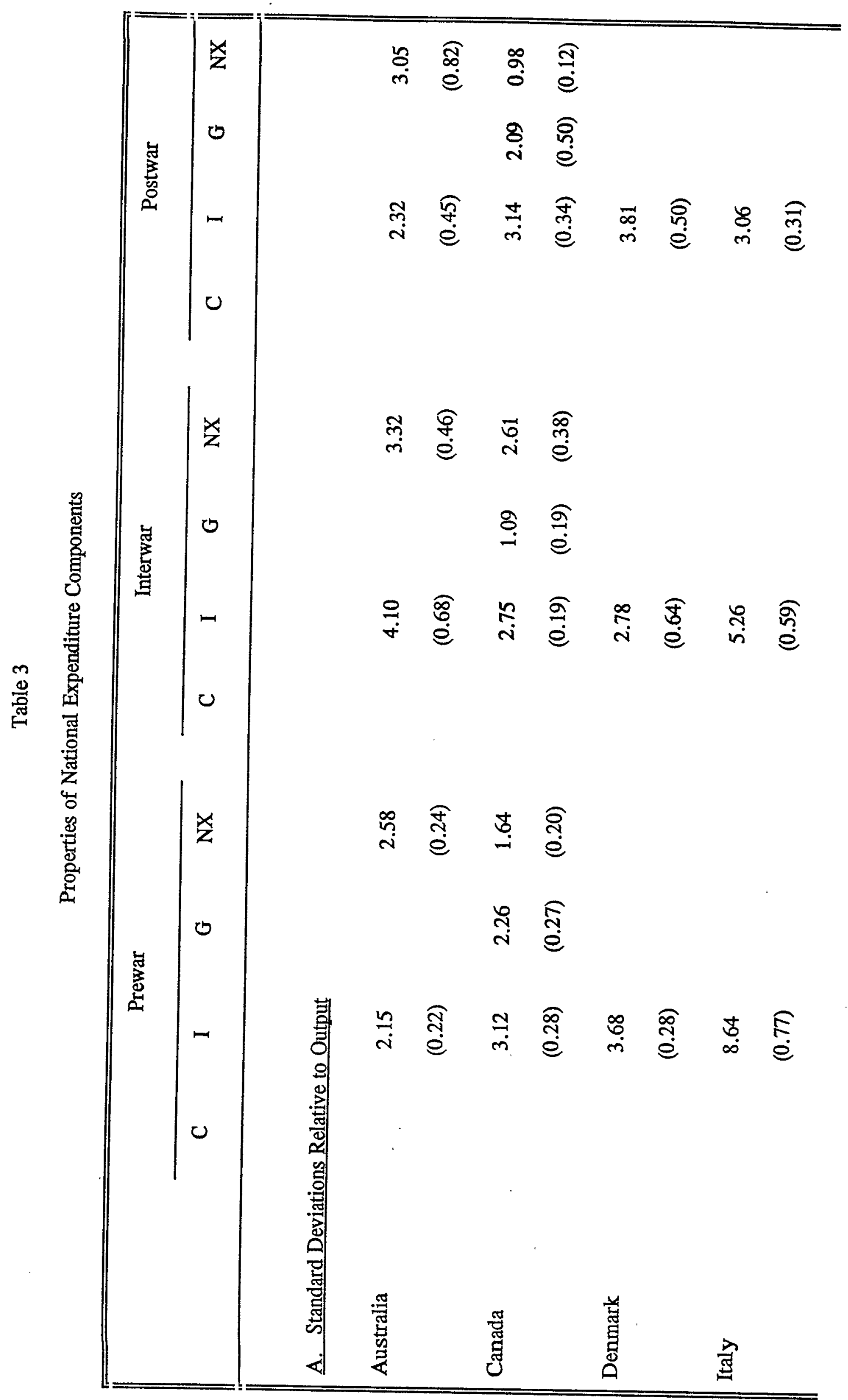




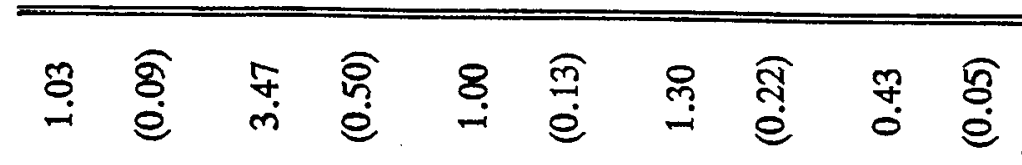

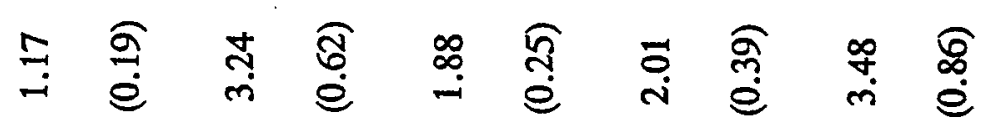

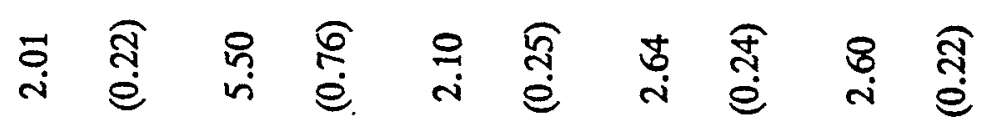

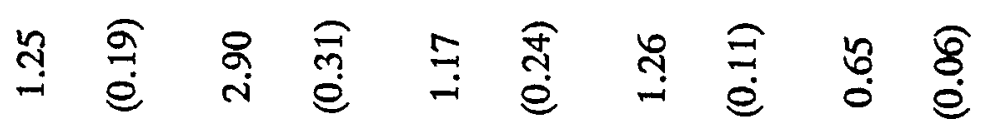

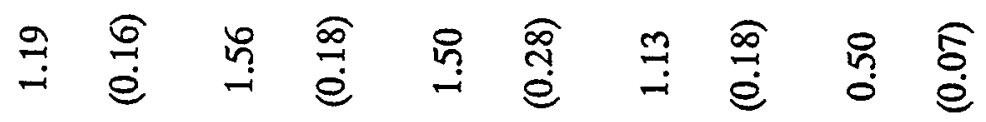

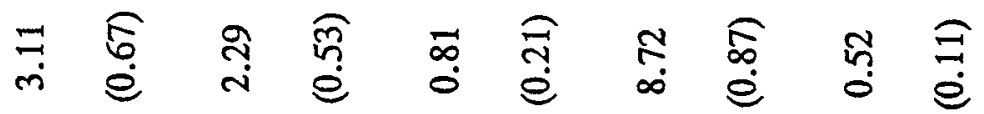

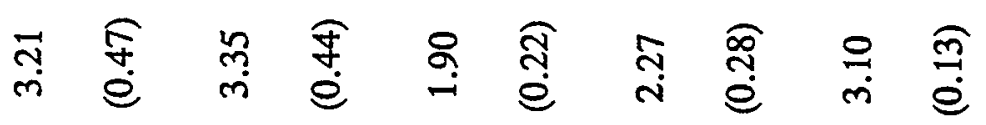

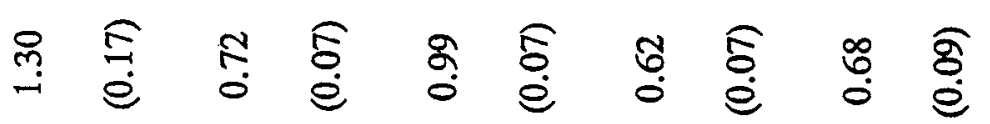

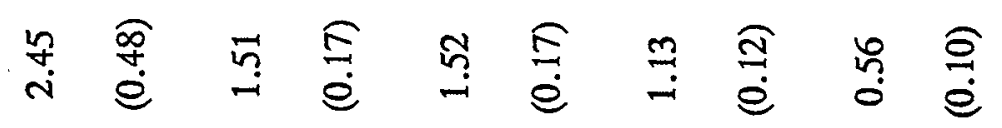

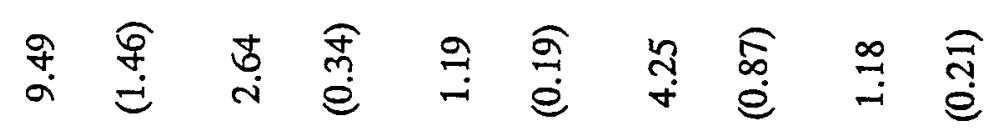

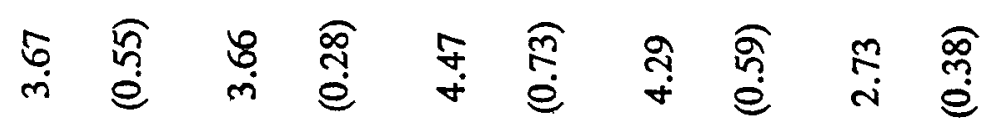

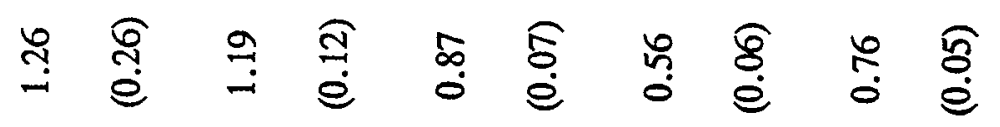




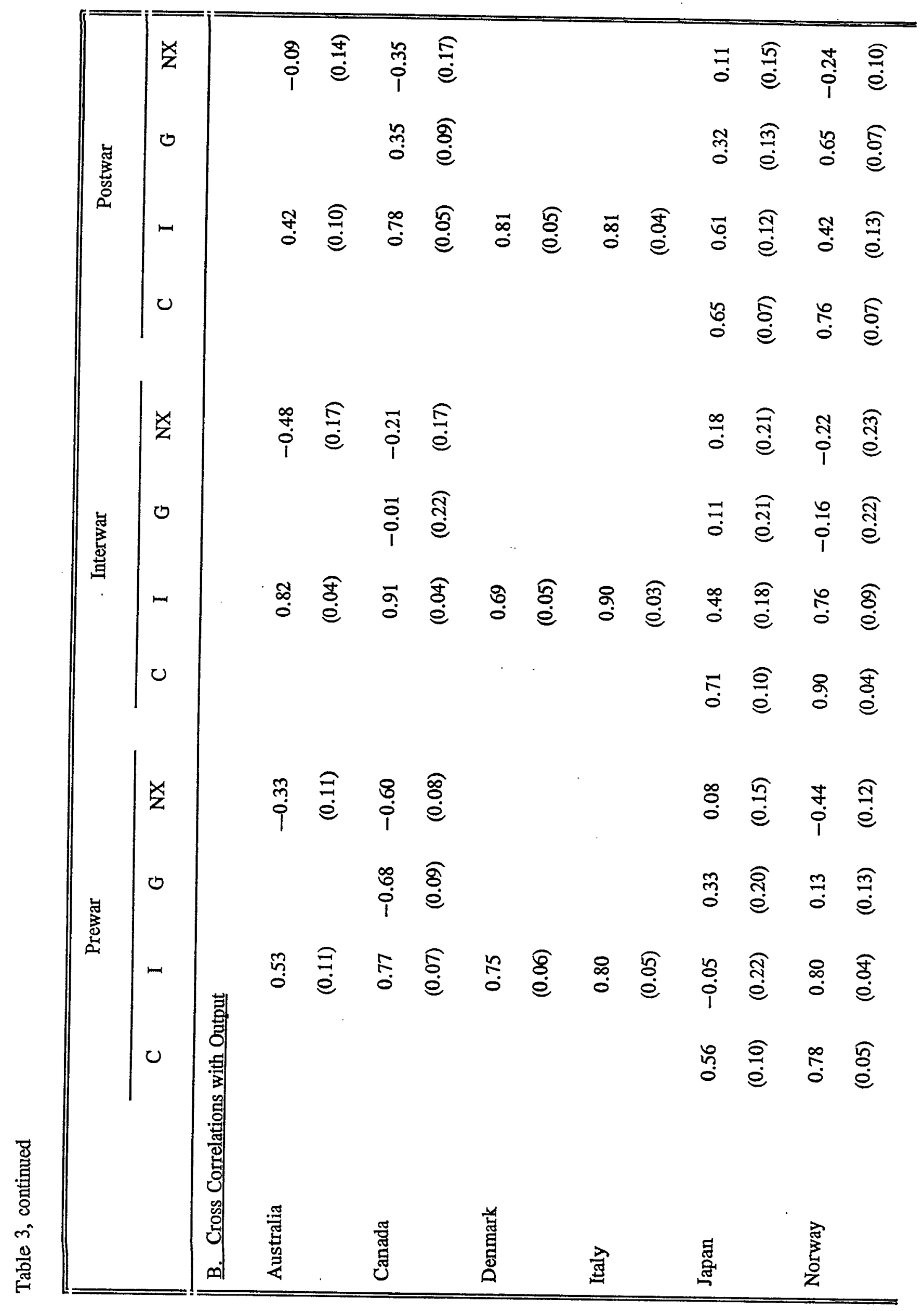




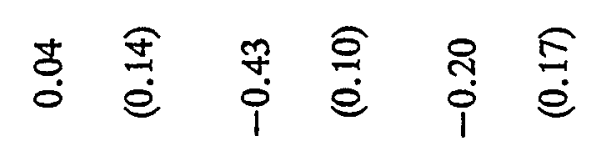

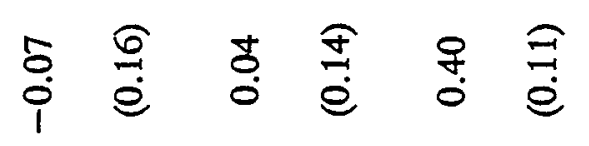

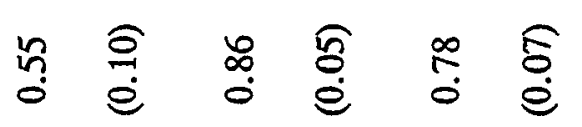

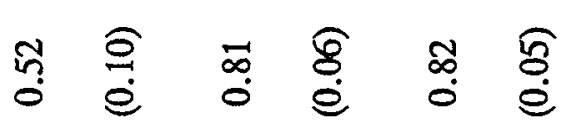

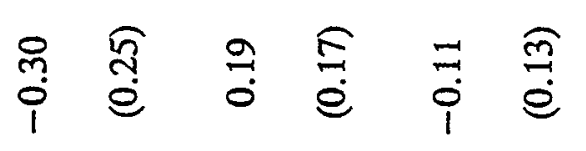

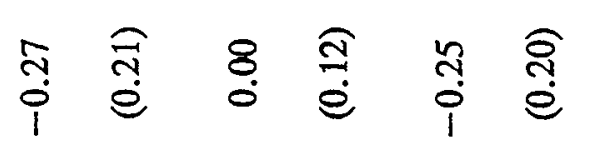

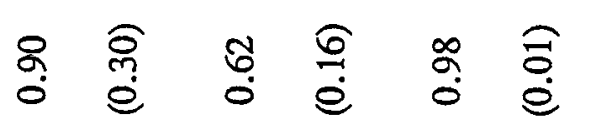

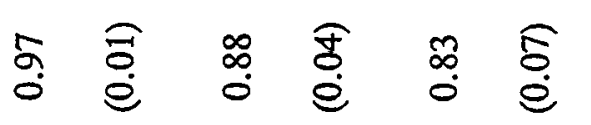

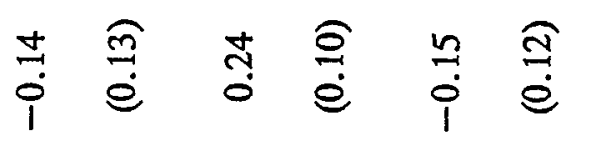

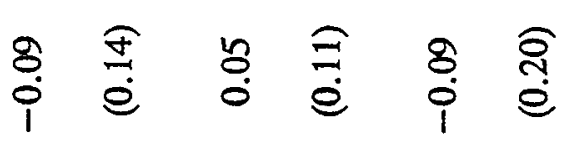

동

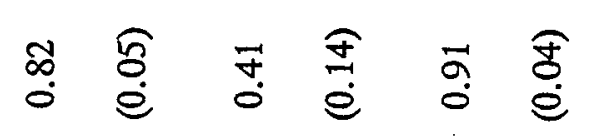

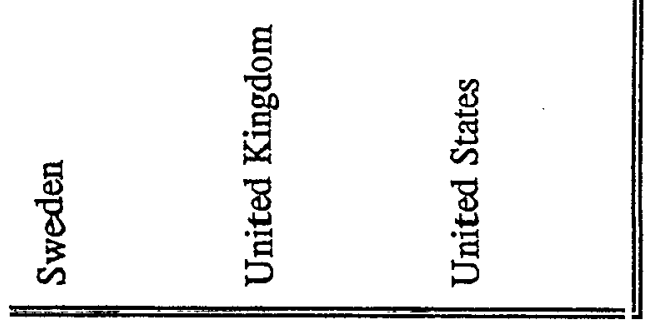

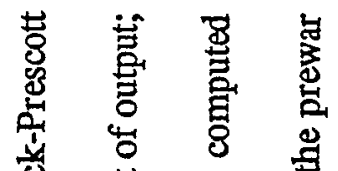

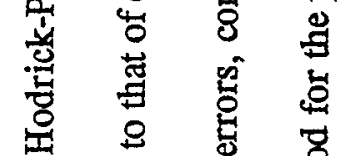

岂 莺 总

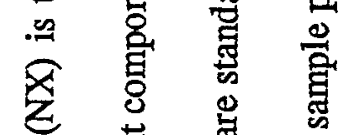

范

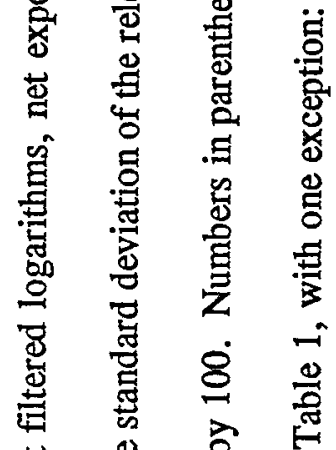

苟

离

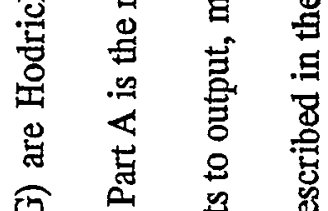

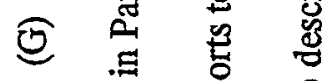

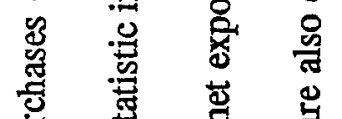

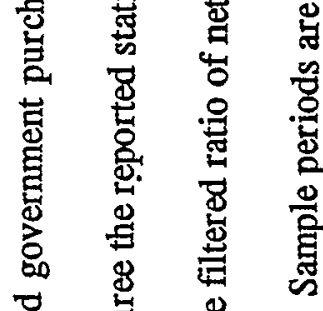

豆 营

苞焉 氶

苞 㟧 营

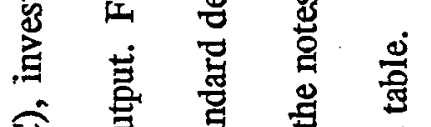

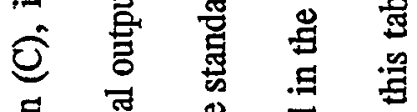

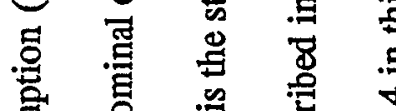

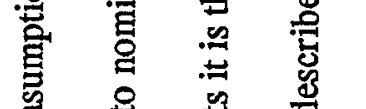

营

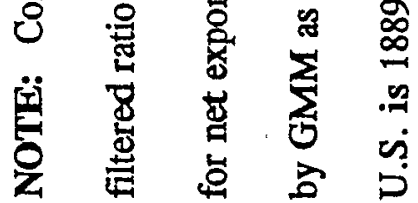




\begin{tabular}{|c|c|c|c|c|c|c|c|c|c|c|c|c|c|c|c|c|}
\hline \multirow{19}{*}{ 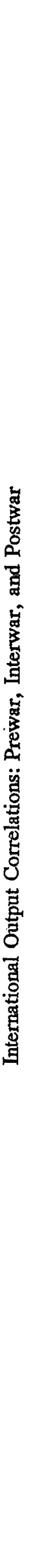 } & $\stackrel{\text { p̊ }}{\rho}$ & $\begin{array}{l}\stackrel{\tilde{2}}{\sigma} \\
\stackrel{0}{0} \\
\stackrel{0}{0}\end{array}$ & 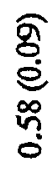 & $\begin{array}{l}\frac{\infty}{1} \\
\stackrel{1}{0} \\
0 \\
0 \\
0\end{array}$ & 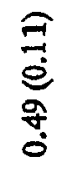 & 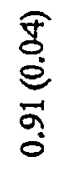 & $\begin{array}{l}\hat{8} \\
\text { é } \\
\text { 范 } \\
0\end{array}$ & 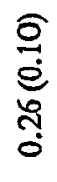 & $\begin{array}{l}\frac{\hat{m}}{0} \\
\stackrel{0}{0} \\
\stackrel{f}{0}\end{array}$ & $\begin{array}{l}\frac{\sigma}{2} \\
\text { end } \\
\text { సุ }\end{array}$ & 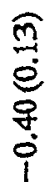 & $\begin{array}{l}\hat{0} \\
0 \\
\stackrel{0}{0} \\
\infty \\
0 \\
0\end{array}$ & 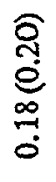 & 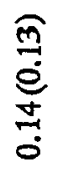 & 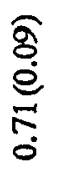 & $\begin{array}{l}E \\
\stackrel{E}{0} \\
\stackrel{0}{n} \\
0\end{array}$ \\
\hline & $\dot{\lambda}$ & 울 & ণ్రి & $\frac{n}{e}$ & $\frac{\hat{0}}{e}$ & $\begin{array}{l}E \\
\stackrel{0}{0}\end{array}$ & $\frac{\sigma}{e}$ & $\begin{array}{l}E \\
e\end{array}$ & ส্ণ & $\frac{\widehat{m}}{\dot{e}}$ & $\frac{\mathfrak{g}}{\dot{e}}$ & $\begin{array}{l}\delta \\
0\end{array}$ & $\stackrel{\widehat{త}}{\stackrel{-}{e}}$ & $\frac{\text { f }}{\stackrel{0}{e}}$ & $\stackrel{\circ}{\stackrel{\circ}{e}}$ & $\stackrel{5}{\mathfrak{c}}$ \\
\hline & 官 & ஜ̊ & $\underset{0}{\mathbb{*}}$ & ్ㅠㅁ & స్ & $\stackrel{0}{\circ}$ & 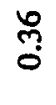 & $\tilde{n}$ & స్ & ஸे & $\begin{array}{l}8 \\
0\end{array}$ & $\begin{array}{l}0 \\
0 \\
0\end{array}$ & $\stackrel{\text { 웅 }}{\circ}$ & $\stackrel{y}{:}$ & 芯 & สุ \\
\hline & 超 & $\stackrel{\widehat{\theta}}{\stackrel{e}{e}}$ & 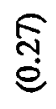 & $\begin{array}{l}\text { o } \\
\stackrel{0}{e}\end{array}$ & $\stackrel{\infty}{\rightleftarrows}$ & $\begin{array}{l}\text { ᄋ } \\
\stackrel{0}{0}\end{array}$ & $\underset{\stackrel{E}{e}}{\stackrel{E}{0}}$ & $\frac{\widehat{E}}{\dot{e}}$ & สู & $\stackrel{n}{e}$ & $\underset{\mathfrak{d}}{\stackrel{f}{0}}$ & $\begin{array}{l}\text { क्ष } \\
e\end{array}$ & 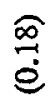 & 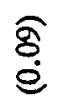 & $\underset{\Xi}{\stackrel{\Xi}{e}}$ & $\stackrel{E}{E}$ \\
\hline & 站 & $\underset{8}{8}$ & 웅 & ڤ̊. & $\stackrel{m}{0}$ & $\begin{array}{l}0 \\
\infty \\
0\end{array}$ & 8̊ & ڤึ? & స్ ర్ & $\overrightarrow{\tilde{n}}$ & $\stackrel{n}{\sigma}$ & $\begin{array}{l}0 \\
0 \\
0\end{array}$ & $\stackrel{N}{0}$ & $\overrightarrow{0}$ & 守 & $\stackrel{ \pm}{0}$ \\
\hline & 害 & $\underset{\Xi}{\stackrel{\Xi}{e}}$ & $\begin{array}{l}\hat{\mathfrak{A}} \\
\stackrel{e}{e}\end{array}$ & $\stackrel{\infty}{?}$ & $\stackrel{\overbrace{}}{\stackrel{9}{e}}$ & $\underset{e}{\stackrel{9}{e}}$ & $\stackrel{5}{\stackrel{n}{e}}$ & 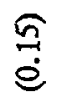 & $\frac{2}{e}$ & $\underset{\mathfrak{e}}{\stackrel{9}{e}}$ & $\underset{ت}{\stackrel{0}{e}}$ & $\underset{\mathfrak{e}}{\mathfrak{e}}$ & తิ & $\underset{\mathfrak{e}}{\stackrel{a}{e}}$ & $\stackrel{2}{\stackrel{9}{e}}$ & $\frac{\widehat{\theta}}{\stackrel{0}{e}}$ \\
\hline & z & 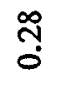 & $\begin{array}{l}8 \\
0 \\
i\end{array}$ & 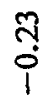 & $\begin{array}{l}0 \\
\dot{1}\end{array}$ & $\stackrel{\mathscr{n}}{\circ}$ & $\stackrel{\text { ñ. }}{0}$ & $\stackrel{ \pm}{:}$ & $\stackrel{\text { I }}{\circ}$ & 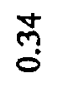 & $\stackrel{ \pm}{ \pm}$ & ले & $\overrightarrow{0}$ & $\begin{array}{l}\text { पे } \\
0 \\
i\end{array}$ & $\vec{\forall}$ & స్ \\
\hline & $\exists$ & 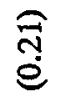 & 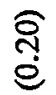 & $\begin{array}{l}0 \\
\stackrel{0}{0} \\
e\end{array}$ & $\frac{f}{d}$ & $\begin{array}{l}\text { ले } \\
\text { હे }\end{array}$ & $\stackrel{\frac{9}{9}}{e}$ & 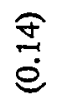 & 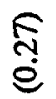 & $\frac{\widehat{9}}{e}$ & $\stackrel{E}{e}$ & 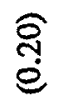 & $\stackrel{\infty}{\stackrel{0}{e}}$ & $\stackrel{\infty}{\stackrel{\infty}{e}}$ & $\begin{array}{l}\text { సิ } \\
\text { હ) }\end{array}$ & $\stackrel{E}{\stackrel{E}{e}}$ \\
\hline & 惫 & $\begin{array}{l}\delta \\
0 \\
i\end{array}$ & $\stackrel{\widehat{઼ ̆}}{0}$ & $\overline{3}$ & $\stackrel{n}{0}$ & $\begin{array}{l}0 \\
0 \\
i\end{array}$ & $\stackrel{\infty}{\stackrel{0}{0}}$ & $\stackrel{\infty}{\circ}$ & ণ్ণ & $\tilde{n}$ & $\underset{0}{ \pm}$ & $\overbrace{0}^{\infty}$ & $\overrightarrow{\tilde{c}}$ & $\stackrel{m}{:}$ & : & กี \\
\hline & & $\stackrel{\widehat{9}}{\stackrel{e}{e}}$ & $\frac{\stackrel{f}{:}}{\stackrel{e}{e}}$ & $\stackrel{E}{e}$ & 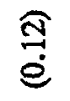 & $\begin{array}{l}\text { } \\
\stackrel{8}{e}\end{array}$ & $\frac{6}{0}$ & $\frac{\Omega}{9}$ & $\stackrel{\infty}{\stackrel{\infty}{e}}$ & $\frac{n}{e}$ & $\frac{\widehat{s}}{\stackrel{e}{e}}$ & $\underset{\vec{E}}{\stackrel{E}{E}}$ & $\stackrel{\stackrel{9}{9}}{\stackrel{0}{e}}$ & & & \\
\hline & $\stackrel{\Phi}{\Xi}$ & สู & ๙ે & $\Xi$ & $\stackrel{2}{0}$ & $\frac{\pi}{5}$ & sọ & $\ddot{0}$ & $\stackrel{10}{0}$ & $\stackrel{n}{n}$ & $\begin{array}{l}8 \\
0\end{array}$ & $\stackrel{\substack{0 \\
0}}{0}$ & $\tilde{n}$ & $\underset{-}{8}$ & $\underset{-}{8}$ & $\underset{-}{8}$ \\
\hline & 夜 & $\stackrel{\text { a }}{e}$ & $\stackrel{\delta}{\delta}$ & $\stackrel{E}{\stackrel{E}{e}}$ & $\frac{0}{e}$ & $\begin{array}{l}8 \\
\dot{8}\end{array}$ & $\stackrel{E}{e}$ & $\stackrel{\text { }}{\stackrel{9}{e}}$ & હे & $\frac{6}{e}$ & & & & & & \\
\hline & 苞 & $\stackrel{\infty}{\dddot{1}}$ & $\begin{array}{l}n \\
\infty \\
0\end{array}$ & $\overrightarrow{\tilde{\sigma}}$ & $\begin{array}{l}\text { స్ } \\
\vdots \\
1\end{array}$ & $\stackrel{\infty}{\circ}$ & $\stackrel{5}{0}$ & $\frac{n}{0}$ & $\begin{array}{l}8 \\
0 \\
0\end{array}$ & స్ & $\stackrel{8}{8}$ & $\underset{-}{8}$ & $\stackrel{8}{8}$ & & & \\
\hline & 㮍 & $\begin{array}{l}\widehat{8} \\
\stackrel{8}{8}\end{array}$ & $\frac{2}{\stackrel{2}{e}}$ & $\frac{6}{e}$ & $\frac{\partial}{e}$ & $\frac{\sqrt{2}}{\stackrel{0}{e}}$ & $\frac{\infty}{\stackrel{\infty}{0}}$ & & & & & & & & & \\
\hline & 目 & స్ "ু & $\begin{array}{l}\dot{O} \\
\dot{0}\end{array}$ & $\stackrel{n}{0}$ & ฟु. & ज़ & $\begin{array}{l}8 \\
0 \\
i\end{array}$ & $\underset{-}{8}$ & $\underset{-}{8}$ & $\underset{-}{8}$ & & & & & & \\
\hline & 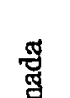 & ब̊ & $\stackrel{\widehat{\Im}}{\stackrel{3}{e}}$ & $\stackrel{5}{e}$ & & & & & & & & & & & & \\
\hline & 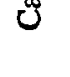 & ⿳亠丷⿵冂丶 & ఫ & ণু & $\underset{-1}{8}$ & $\stackrel{8}{-}$ & $\stackrel{8}{-}$ & & & & & & & & & \\
\hline & 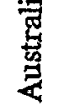 & $\underset{-}{8}$ & $\stackrel{8}{8}$ & $\underset{-}{8}$ & & & & & & & & & & & & \\
\hline & & 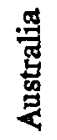 & & & 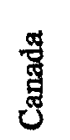 & & & $\begin{array}{l}\text { 曾 } \\
\text { 貝 } \\
\text { 虽 }\end{array}$ & & & 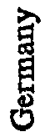 & & & 宓 & & \\
\hline
\end{tabular}




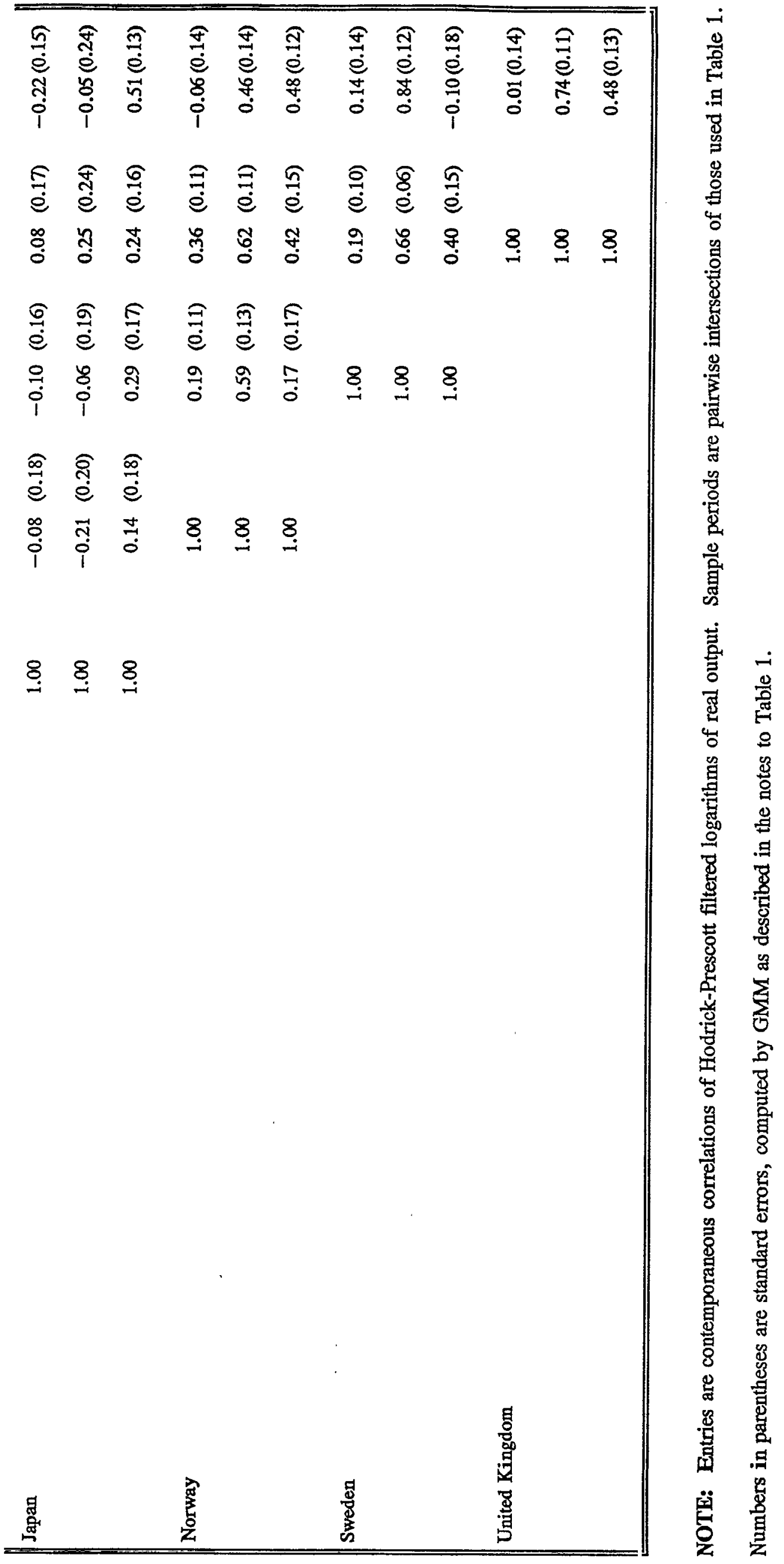




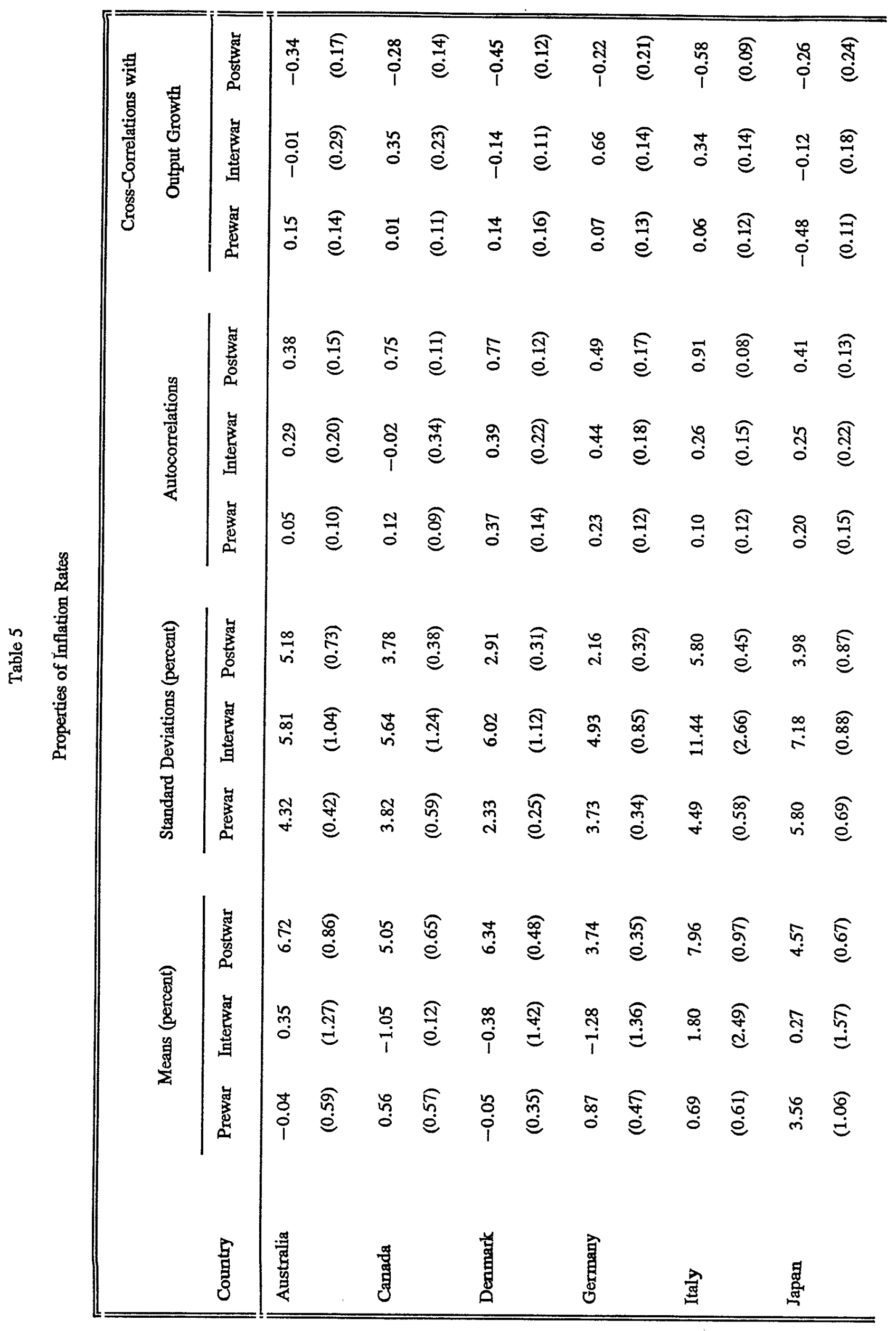




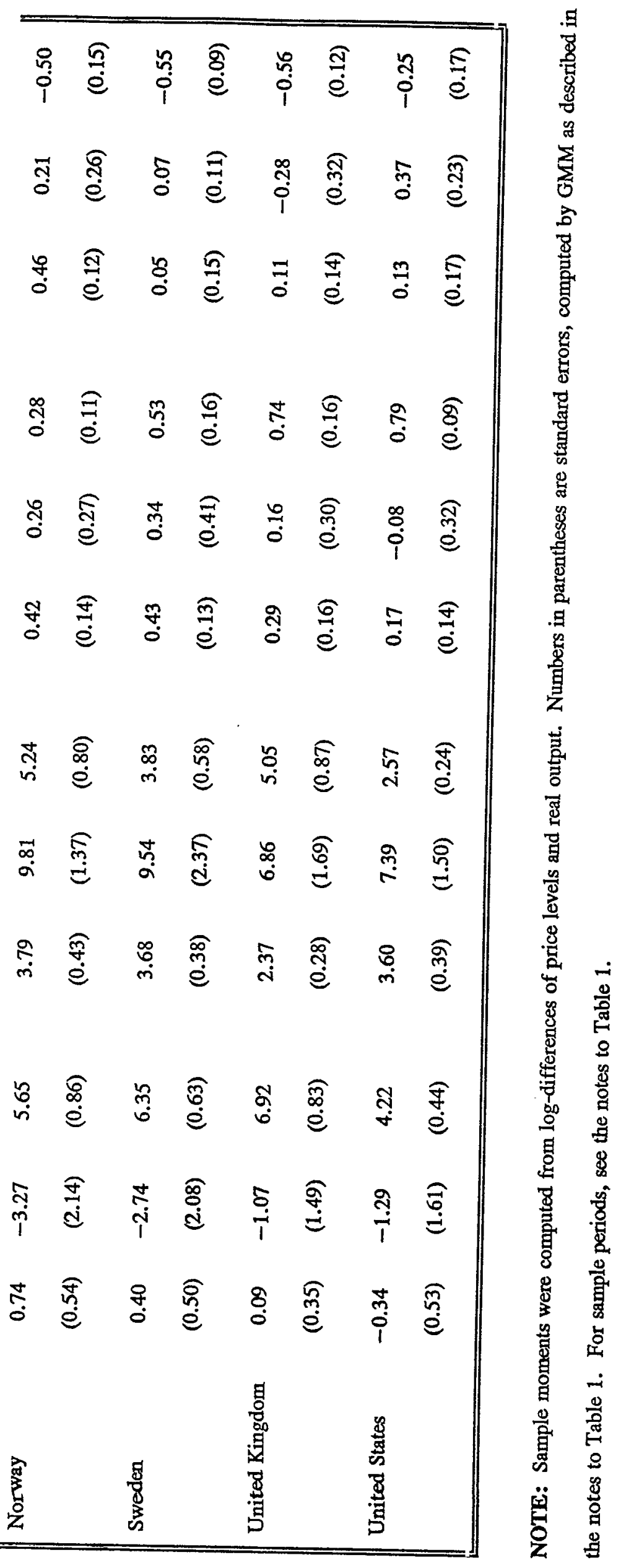


Table 6

Properties of Price Level Fluctuations

\begin{tabular}{|c|c|c|c|c|c|c|}
\hline \multirow[b]{2}{*}{ Country } & \multicolumn{3}{|c|}{ Standard Deviations (Percent) } & \multicolumn{3}{|c|}{ Cross-Correlations with Output } \\
\hline & Prewar & Interwar & Postwar & Prewar & Interwar & Postwar \\
\hline \multirow[t]{2}{*}{ Australia } & 3.89 & 6.28 & 4.80 & 0.60 & 0.59 & -0.47 \\
\hline & $(0.33)$ & $(0.79)$ & $(0.73)$ & $(0.10)$ & $(0.12)$ & $(0.11)$ \\
\hline \multirow[t]{2}{*}{ Canada } & 3.46 & 4.63 & 2.53 & 0.41 & 0.77 & 0.12 \\
\hline & $(0.30)$ & $(0.56)$ & $(0.38)$ & $(0.13)$ & $(0.08)$ & $(0.16)$ \\
\hline \multirow[t]{2}{*}{ Denmark } & 2.38 & 5.99 & 1.95 & 0.18 & -0.26 & -0.48 \\
\hline & $(0.20)$ & $(0.81)$ & $(0.18)$ & $(0.12)$ & $(0.25)$ & $(0.11)$ \\
\hline \multirow[t]{2}{*}{ Germany } & 3.91 & 5.33 & 2.08 & -0.01 & 0.71 & 0.01 \\
\hline & $(0.39)$ & $(0.65)$ & $(0.28)$ & $(0.15)$ & $(0.09)$ & $(0.16)$ \\
\hline \multirow[t]{2}{*}{ Italy } & 3.82 & 10.89 & 4.15 & -0.02 & 0.58 & -0.24 \\
\hline & $(0.45)$ & $(1.28)$ & $(0.46)$ & $(0.11)$ & $(0.09)$ & $(0.14)$ \\
\hline \multirow[t]{2}{*}{ Japan } & 5.39 & 7.62 & 4.26 & -0.45 & 0.03 & -0.60 \\
\hline & $(0.58)$ & $(0.85)$ & $(0.34)$ & $(0.11)$ & $(0.22)$ & $(0.10)$ \\
\hline \multirow[t]{2}{*}{ Norway } & 3.99 & 7.78 & 4.54 & 0.65 & 0.16 & -0.63 \\
\hline & $(0.40)$ & $(0.92)$ & $(0.45)$ & $(0.08)$ & $(0.19)$ & $(0.08)$ \\
\hline \multirow[t]{2}{*}{ Sweden } & 4.02 & 8.60 & 3.09 & 0.15 & 0.30 & -0.53 \\
\hline & $(0.28)$ & $(1.32)$ & $(0.50)$ & $(0.13)$ & $(0.10)$ & $(0.07)$ \\
\hline
\end{tabular}




\begin{tabular}{||ccccccc||} 
United Kingdom & 2.43 & 4.94 & 4.96 & 0.26 & 0.20 & -0.50 \\
& $(0.32)$ & $(0.95)$ & $(0.59)$ & $(0.12)$ & $(0.21)$ & $(0.14)$ \\
United States & 3.04 & 6.25 & 1.47 & 0.22 & 0.72 & -0.30 \\
& $(0.39)$ & $(0.95)$ & $(0.14)$ & $(0.11)$ & $(0.13)$ & $(0.16)$ \\
\hline
\end{tabular}

NOTE: Sample moments were computed from Hodrick-Prescott filtered logarithms of price levels and real output. Numbers in parentheses are standard errors, computed by GMM as described in the notes to Table 1. Sample periods are also given in the notes to Table 1. 


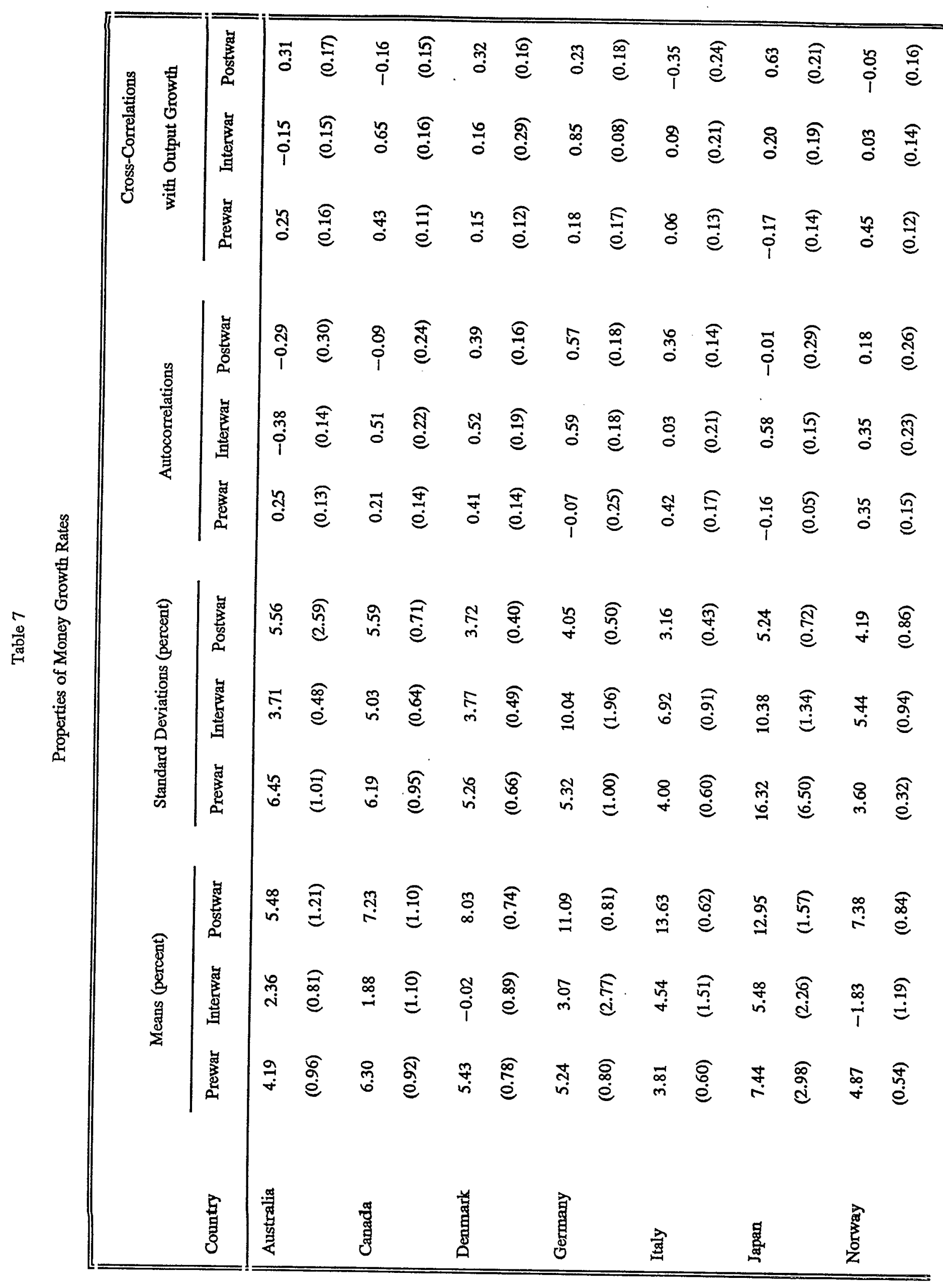




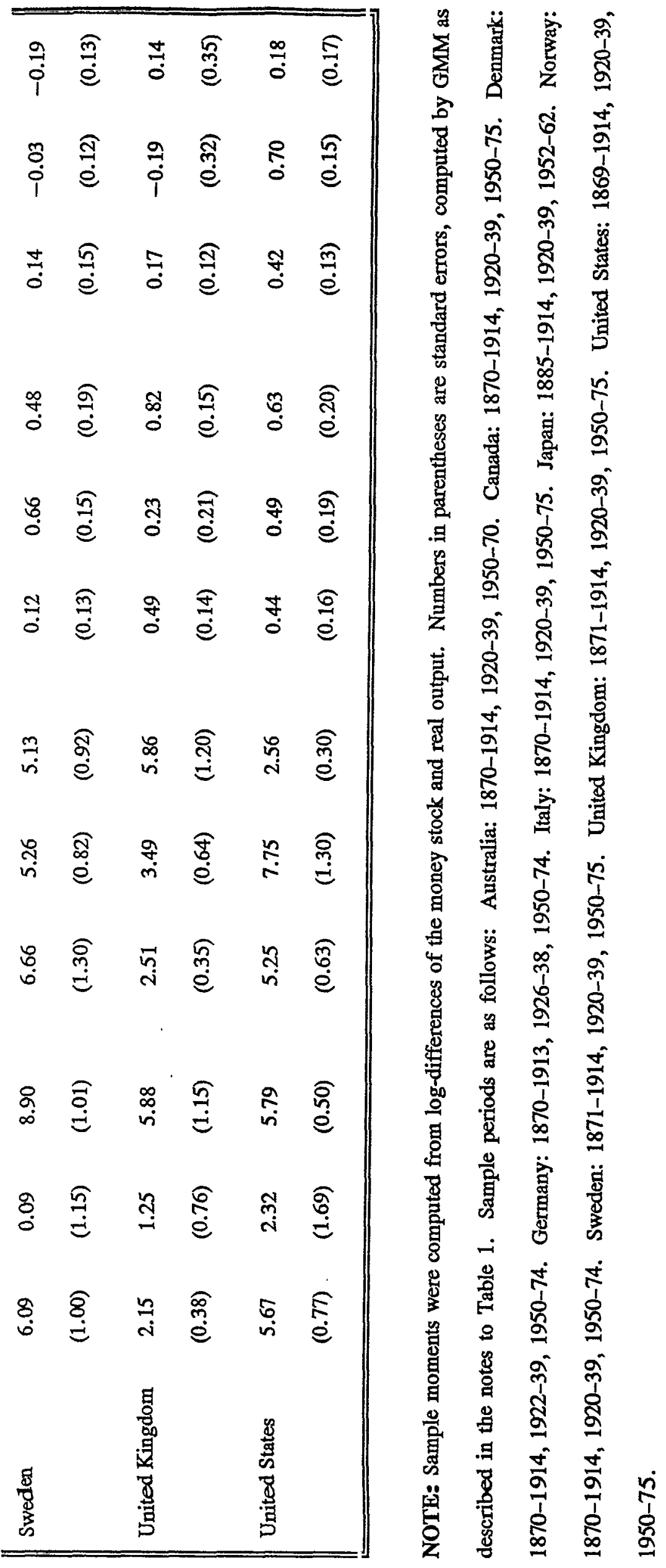




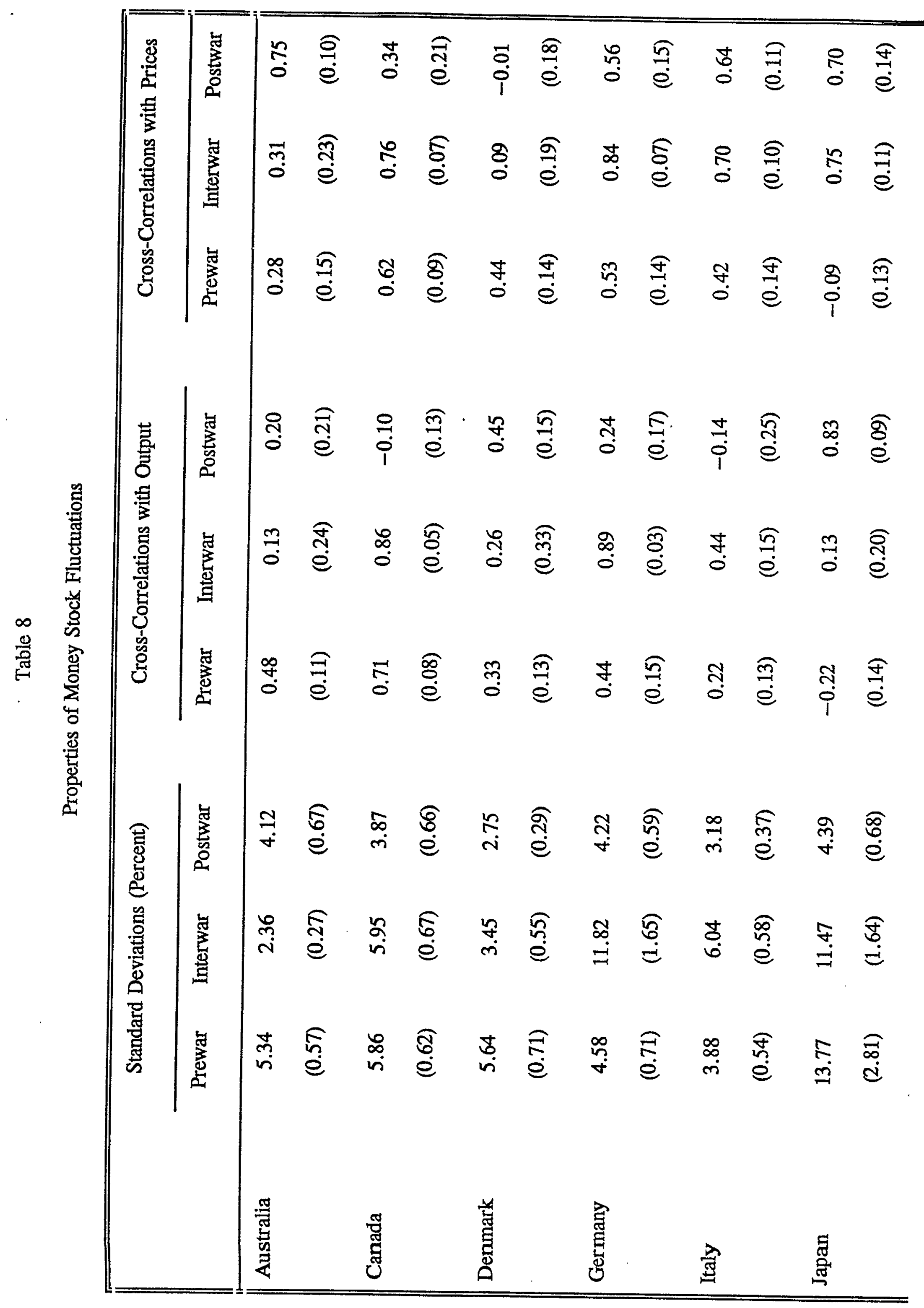




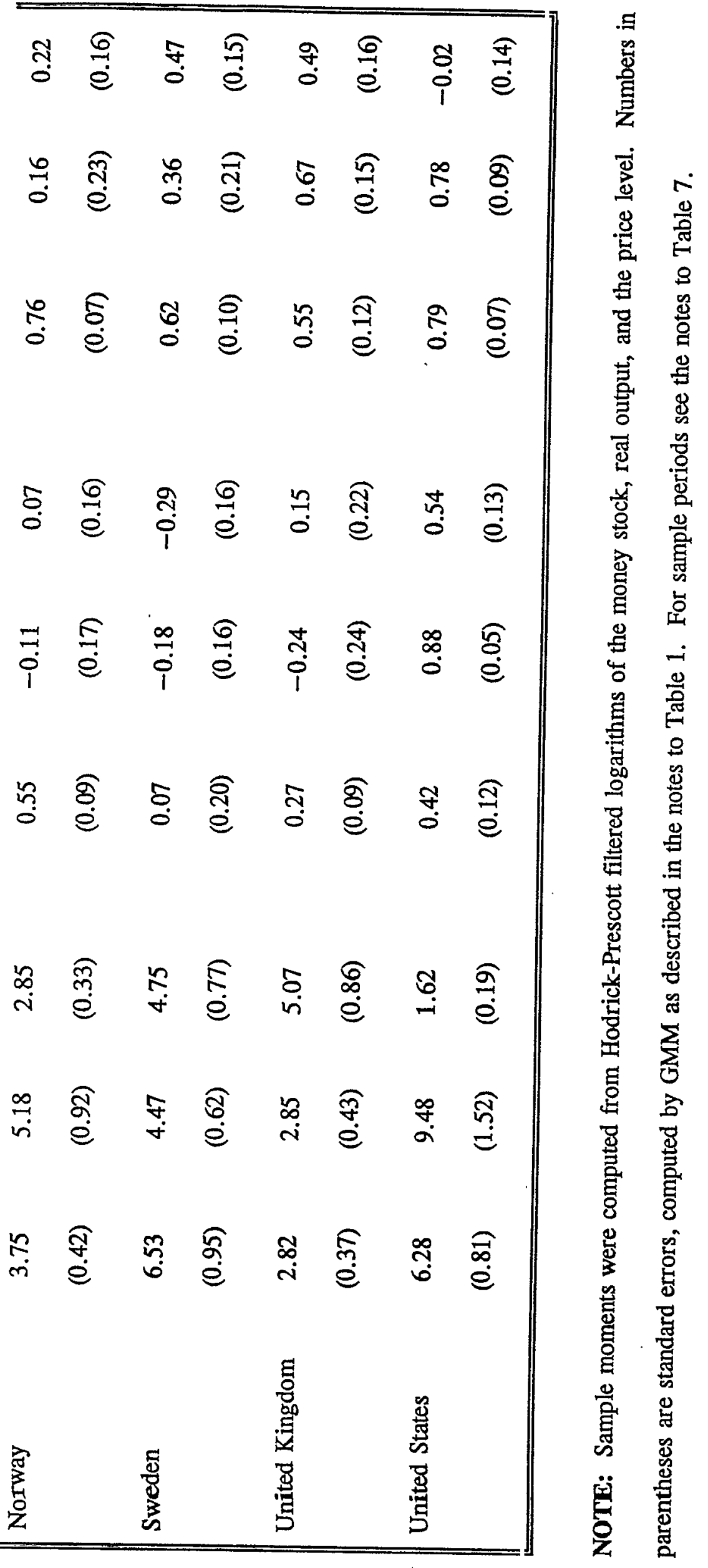

